\title{
1 Seasonal and long-term consequences of esca on grapevine stem xylem \\ 2 integrity
}

3 Running title: Impact of the trunk disease esca on stem hydraulic integrity

4

5 Highlight: Our study reveals that esca can critically affect xylem water movement in grapevine

6 perennial organs, by the presence of plant-derived tyloses.

7

8 G. Bortolami $^{\mathrm{a}}$, E. Farolfi ${ }^{\mathrm{a}}$, E. Badel ${ }^{\mathrm{b}}$, R. Burlett ${ }^{\mathrm{c}}$, H. Cochard ${ }^{\mathrm{b}}$, N. Ferrer ${ }^{\mathrm{a}}$, A. King ${ }^{\mathrm{d}}$, L.J.

9 Lamarque $^{\text {c,e }}$, P. Lecomte ${ }^{\mathrm{a}}$, M. Marchesseau-Marchal ${ }^{\mathrm{a}}$, J. Pouzoulet ${ }^{\mathrm{f}}$, J.M. Torres-Ruiz ${ }^{\mathrm{b}}$, S.

10 Trueba ${ }^{\mathrm{c}, \mathrm{g}}, \mathrm{S}$. Delzon ${ }^{\mathrm{c}}$, G.A. Gambetta ${ }^{\mathrm{f}}$, C.E.L. Delmas ${ }^{\mathrm{a}^{*}}$

aINRAE, BSA, ISVV, SAVE, 33882 Villenave d'Ornon, France

bUniversité Clermont-Auvergne, INRAE, PIAF, 63000 Clermont-Ferrand, France

14 'Univ. Bordeaux, INRAE, BIOGECO, 33615 Pessac, France

${ }^{\mathrm{d} S y n c h r o t r o n ~ S O L E I L, ~ L ' O r m e ~ d e s ~ M e r i s i e r s, ~ G i f-s u r-Y v e t t e, ~ 91192, ~ F r a n c e ~}$

eDépartement des Sciences de l'Environnement, Université du Québec à Trois-Rivières, Trois-

17 Rivières, Québec, G9A 5H7, Canada

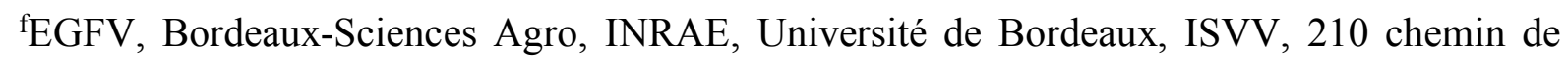
Leysotte, 33882 Villenave d'Ornon, France

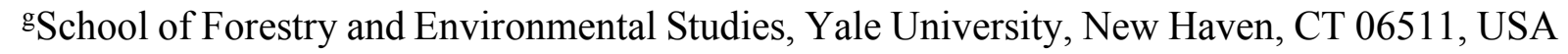

*Author for correspondence

24 chloe.delmas@inrae.fr 


\section{ABSTRACT}

28 Hydraulic failure has been extensively studied during drought-induced plant dieback, but its 29 role in plant-pathogen interactions is under debate. During esca, a grapevine (Vitis vinifera) 30 disease, symptomatic leaves are prone to irreversible hydraulic dysfunctions but little is known about the hydraulic integrity of perennial organs over the short- and long-term. We investigated the effects of esca on stem hydraulic integrity in naturally infected plants within a single season and across season(s). We coupled direct $\left(k_{s}\right)$ and indirect $\left(k_{t h}\right)$ hydraulic conductivity measurements, and tylose and vascular pathogen detection with in vivo X-ray microtomography visualizations. We found xylem occlusions (tyloses), and subsequent loss of stem $k_{s}$, in all of the shoots with severe symptoms (apoplexy) and in more than $60 \%$ of the shoots with moderate symptoms (tiger-stripe), and no tyloses in shoots that were currently asymptomatic. In vivo stem observations demonstrated that tyloses were observed only when leaf symptoms appeared, and resulted in more than 50\% PLC in 40\% of symptomatic stems, unrelated to symptom age. The impact of esca on xylem integrity was only seasonal and no long-term impact of disease history was recorded. Our study demonstrated how and to what extent a vascular disease such as esca, affecting xylem integrity, could amplify plant mortality by hydraulic failure.

45 Key words: Esca, hydraulic failure, plant dieback, tyloses, vascular pathogens, Vitis vinifera 
In agricultural and forest ecosystems, perennial plant dieback causes decreases in plant productivity and longevity (Aleemullah and Walsh, 1996; Eskalen et al., 2013; Urbez-Torres et al., 2013; Alvindia and Gallema, 2017). Plant dieback is a complex process where different biotic and/or abiotic stress factors interact and contribute to leaf and crown wilting and ultimately plant death (Desprez-Lostau et al., 2006; Anderegg et al., 2013, Cailleret et al., 2017; Bettenfeld et al., 2020). Drought-mediated plant dieback has been extensively studied, and in this case hydraulic failure has been identified as the primary cause of plant death (Anderegg et al., 2016). Hydraulic failure results from an interruption of the ascendant water flow by air embolism or xylem occlusion (Zimmermann, 1979; Tyree and Sperry, 1989). Vascular pathogens, which infect the xylem network (Yadeta and Thomma, 2013), are also important drivers of pathogen-mediated plant dieback (Goberville et al., 2016; Pandey et al., 2018; Fallon et al., 2020).

Vascular pathogens induce wood necrosis, leaf symptoms, and crown defoliation (Beckmann and Roberts, 1995; Pearce, 1996). Their biology and toxic metabolite production has been well studied, in particular using controlled phytotoxicity assays (Andolfi et al., 2011; Akpaninyang and Opara, 2017). However, the possible role of hydraulic failure during pathogen-mediated plant dieback has been poorly investigated, and the underlying physiological mechanisms inducing leaf symptoms are not clear yet (Fradin and Thomma, 2006; McDowell et al., 2008). Moreover, the long-term impact (over seasons) and relationships between pathogens, leaf symptom presence, and the hydraulic functioning of the plant are still unknown. During vascular pathogenesis, both air (Pérez-Donoso et al., 2016) and nongaseous (Sun et al., 2013; Czemmel et al., 2015, Pouzoulet et al., 2019) embolism have been observed. For example, air embolism is thought to accelerate pathogen progression during Pierce's disease (Pérez-Donoso et al., 2016), and nongaseous embolism is associated with occlusion of the xylem conduits by the plant that could slow the disease process while interfering with xylem water transport (Sun et al., 2013; Pouzoulet et al., 2019).

Xylem occlusion, usually through the production of tyloses and gels, is one of the first plant defense mechanisms against vascular pathogens (Pearce, 1996). Xylem parenchyma cells secrete gels and expand into the vessel lumen, forming tyloses, physically blocking pathogen progression (Zimmermann, 1979). Xylem anatomy plays an important role, both for vascular pathogen development (Martin et al., 2009; Martín et al., 2013; Venturas et al., 2014; 
Pouzoulet et al., 2017; 2020) and for tylose formation (Bonsen and Kucera, 1990; De Micco et al., 2016; Pouzoulet et al., 2019). If effective, this occlusion mechanism allows the plant to compartmentalize the infected zone and to generate new tissue around it (CODIT model, Pearce, 1996). Because tyloses can potentially interfere with the hydraulic functioning of the plant, they could exacerbate disease symptoms (Talboys, 1972). Tyloses are usually observed in close proximity to pathogens, as shown in artificial inoculation studies (Czemmel et al., 2015; Rioux et al., 2018, among others). However, pathogens frequently proliferate in perennial organs without physically reaching the leaves, thus leaf symptoms are often induced at a distance (Beckmann and Roberts, 1995). A recent study shows that tyloses can be present in symptomatic leaves at a distance from the pathogen niches resulting in decreased leaf hydraulic conductivity (Bortolami et al., 2019).

Over the last decades, grapevine (Vitis vinifera L.) mortality and yield loss have been reported in European, American, and South African vineyards due to esca trunk disease (Cloete et al., 2015; Guerin-Dubrana et al., 2019). Esca, a vascular disease caused by the infection of multiple fungal pathogens, affects mostly mature grapevines (more than seven-years-old), and symptoms include trunk necrosis and leaf symptoms, consisting of "tiger-stripe" necrosis and leaf wilting (Lecomte et al., 2012; Claverie et al., 2020), which are not regularly expressed season-to-season even within individual vines (Guerin-Dubrana et al., 2013; Li et al., 2017). While the pathogens responsible for esca-induced trunk necrosis have been identified (Morales-Cruz et al., 2018; Brown et al., 2020), the underlying mechanisms of leaf and fruit symptoms, and plant death are still poorly understood. Bortolami et al. (2019) demonstrated that the two vascular pathogens related to esca (Phaeomoniella chlamydospora and Phaeoacremonium minimum) were never detected in leaves or in stems of the current year, but always in the trunk (independently from leaf symptom presence). They further showed that esca symptomatic leaves presented significant losses in hydraulic conductivity due to the occlusion of the xylem conduits by tyloses. Together, these results reveal that esca impacts leaf hydraulic functioning, but whether or not there is a corresponding failure in perennial organs, and the exact timing of this phenomenon, are still unknown. As stems and branches are the direct connections between the pathogen niche in the trunk and the observed symptoms in the leaves, the study of stem xylem integrity is crucial in the understanding of esca impact on grapevine physiology in the current year and across seasons. 
110 In this study, we investigated stem xylem integrity in grapevine during esca leaf symptom

111 formation asking the following questions: (i) Can esca lead to hydraulic failure in perennial 112 organs? (ii) Does stem hydraulic failure occur prior to or after leaf symptom expression, and 113 does it depend on xylem anatomy? (iii) Do long-term symptomatic plants present different 114 xylem anatomy and levels of hydraulic failure from long-term asymptomatic plants? To answer 115 these questions, we transplanted 28-years-old grapevines (Vitis vinifera L. cv Sauvignon blanc) 116 from the field into pots to transport, manipulate, and study naturally esca-infected vines. We coupled in vivo visualizations of stem xylem functionality (using synchrotron-based X-ray microcomputed tomography) with stem specific hydraulic conductivity measurements $\left(k_{s}\right)$, theoretical hydraulic conductivity estimates $\left(k_{t h}\right)$, optical observations of vessel occlusions, and pathogen detection during symptom appearance, while comparing plants with different symptom history record.

MATERIALS AND METHODS

\section{Plant material}

125

Vitis vinifera cv. Sauvignon blanc grafted onto 101-14 MGt were uprooted in winter 2017, 2018, and 2019 from a vineyard planted in 1992 located at INRAE Bordeaux-Nouvelle Aquitaine $\left(44^{\circ} 47^{\prime} 24.8^{\prime \prime} \mathrm{N}, 0^{\circ} 34^{\prime} 35.1^{\prime \prime} \mathrm{W}\right)$ and transferred into pots. Following plant excavation, the root system (around $0.125 \mathrm{~m} 3$ ) was immersed under water overnight, and powered with indole-3-butyric acid. The plants were potted in 201 pots in fine clay medium (Klasmann Deilmann substrate 4:264) and placed on heating plates at $30{ }^{\circ} \mathrm{C}$ for two months. Plants were then moved to a greenhouse, under natural light conditions, and watered with nutritive solutions (0.1 mM NH4H2PO4, 0.187 mM NH4NO3, 0.255 mM KNO3, 0.025 mM MgSO4, 0.002 mM $\mathrm{Fe}$, and oligo-elements [B, $\mathrm{Zn}, \mathrm{Mn}, \mathrm{Cu}$, and $\mathrm{Mo}]$ ) until the end of experiment. Since the plantation these plants have been trained with a double Guyot system. This training system requires a permanent main trunk and one cane on each side of the trunk which is left every year to carry the buds that will produce the stems of the year. During the growing season, the stems of the current year were trimmed at $1.5-2 \mathrm{~m}$, the secondary stems and inflorescences were removed just after bud-break. Each of these plants has been surveyed each year in the field since 2012 for esca leaf symptom expression following Lecomte et al. (2012), and has been classified yearly as leaf-symptomatic or asymptomatic. Plants were then classified by their 
long-term symptomatology record: plants asymptomatic from 2012 to 2018 (pA, previously asymptomatic), and plants that have expressed symptoms at least once between 2012 and 2018 (pS, previously symptomatic).

\section{Esca symptom notation}

The evolution of esca leaf symptoms was surveyed twice a week from June to October 2019 on every plant ( $n=84$, Fig. 1). As presented in Fig. 1A, esca symptoms were scored at the stem and whole plant scales. The stems of the current year collected for analyses (both hydraulic measurements or microCT observations) could be noted as: asymptomatic (green leaves and apparently healthy), pre-symptomatic (leaves presenting yellowing or small yellow spots between the veins), tiger-stripe (typical pattern of esca leaf symptoms), or apoplectic (leaves passing from green to wilted in a couple of days). Along the experimentation, entire plants could be noted as asymptomatic (control) or symptomatic (when at least $25 \%$ of the canopy was presenting tiger-stripe leaf symptoms). At the end of the experiment (week 40, October 2019) each plant was classified as symptomatic or asymptomatic (control). We were then able to group each stem measured into six different groups (Fig. 1A): one group of stems from control plants (asymptomatic from June to October) and five groups of stems from symptomatic plants: two before symptom appearance (asymptomatic and pre-symptomatic stems); and three after symptom appearance (asymptomatic, tiger-stripe, and apoplectic stems). To clearly differentiate asymptomatic stems collected from symptomatic plants and asymptomatic stems collected from asymptomatic plants, we considered plants (and their stems) that didn't show leaf symptoms during the experiment as control plants (or stems). We investigated whether symptom expression (final symptom notation in October 2019, see Fig. 1) differed between plants with contrasted long-term symptom history (previously asymptomatic vs previously symptomatic, Table 1) using a Chi-square test of independence.

\section{X-ray microCT observation}

Synchrotron-based microCT was used to visualize the content of vessels and their functionality in esca tiger-stripe and control stems. Three symptomatic plants (presenting tiger-stripe symptoms for 8,7 , and 3 weeks), and one asymptomatic-control plant were brought to the PSICHE beamline (King et al., 2016) at SOLEIL synchrotron facility in September 2019. Stems of the current year (ca. $2 \mathrm{~m}$ long) were cut under water and transferred into a solution 
containing $75 \mathrm{mM}$ of contrasting agent iohexol. The iohexol solution absorbs X-rays very strongly and appears bright white in X-ray scans above the iodine K-edge at $33.2 \mathrm{keV}$, and, once it has been taken up by the transpiration stream, the effective functionality of each vessel can be confirmed (Pratt and Jacobsen, 2018; Bortolami et al., 2019). These stems were moved and left outdoor to transpire the solution for at least half a day. The stems were then transferred to the beamline stage and scanned twice in less than 5 minutes using two different energies of a high-flux $\left(3 \times 10^{11}\right.$ photons $\left.\mathrm{mm}^{-2}\right)$ monochromatic X-ray beam: $33.1 \mathrm{keV}$ and $33.3 \mathrm{keV}$. The projections were recorded with a sCMOS camera equipped with a 250 -mm-thick LuAG scintillator (Orca Flash, Hamamatsu, Japan). The complete tomographic scan included 1500 projections, and each projection lasted $50 \mathrm{~ms}$. Tomographic reconstructions were performed using PyHST2 software (Mirone et al., 2014) using the Paganin method (Paganin et al., 2002), resulting in 32-bit volume reconstructions of $2048 \times 2048 \times 1024$ voxels. The final spatial resolution was $2.8769 \mu \mathrm{m}^{3}$ voxel $^{-1}$.

\section{Image analysis of microCT scans}

The contrast agent iohexol allowed us to distinguish in intact scans the effective functionality of each vessel. In the absence of iohexol, X-ray microCT scans are used to distinguish air-filled vessels (appearing black, corresponding to native PLC) from sap-filled vessels (appearing grey). The addition of iohexol in the xylem sap allows to distinguish the functional vessels (they appear bright white when they transport the sap), from the non-functional ones (i.e. occluded vessels remaining grey, corresponding to occlusion PLC). We could also observe partially occluded vessels (i.e. vessels with simultaneous presence of air and occlusions, or sap and occlusions). This specific case was observed by checking the presence of any occlusion in at least 200 slices in each volume. Partially occluded vessels were considered as occluded, some examples are presented in Fig. S1. The equivalent-circle diameter of air-filled, occluded, and functional (iohexol-filled) vessels was measured on the cross sections from the central slice of the microCT scanned volume using ImageJ software (Schneider et al., 2012). In the high energy scans recorded at $33.3 \mathrm{keV}$ X-ray beam, iohexol appears bright white but its contrast can sometimes impede the clear limit of the vessel lumen. Therefore, all vessel diameters were recorded on the scan recorded at low energy (33.1 keV X-ray beam), then the distinction of occluded from iohexol-filled vessels was done on the high energy scan (as done by Bortolami et al. 2019). The theoretical hydraulic conductivity of each vessel $\left(k_{\text {vessel }}\right)\left[\mathrm{kg} \mathrm{m} \mathrm{MPa}^{-1} \mathrm{~s}^{-1}\right]$ was calculated using the Hagen-Poiseuille equation: 


$$
k_{\text {vessel }}=\frac{\left(\pi \times \emptyset^{4} \times \rho\right)}{(128 \times \eta)}
$$

205 Where: $\varnothing$ is the equivalent circle diameter [m], $\rho$ the density of water [ $998.2 \mathrm{~kg} \mathrm{~m}-3$ at $\left.20^{\circ} \mathrm{C}\right]$, and $\eta$ the viscosity of water $\left[1.002 \times 10-9 \mathrm{MPa} \mathrm{s}\right.$ at $\left.20^{\circ} \mathrm{C}\right]$. The percentage loss of hydraulic conductivity given by native air embolism (native PLC) was calculated by the ratio between the hydraulic conductivity of air-filled vessels and the whole-stem hydraulic conductivity:

$$
\text { Native PLC }(\%)=100 \times \frac{\left(\sum k_{\text {air }- \text { filled vessels }}\right)}{\left(\sum k_{\text {all vessels }}\right)}
$$

The percentage loss of hydraulic conductivity given by occlusions (occlusion PLC) was calculated by the ratio between occluded (plus partially occluded) vessels and the whole-stem hydraulic conductivity:

$$
\text { Occlusion PLC }(\%)=100 \times \frac{\left(\sum k_{\text {occluded vessels }}+\sum k_{\text {partially occluded vessels }}\right)}{\left(\sum k_{\text {all vessels }}\right)}
$$

The total percentage loss of hydraulic conductivity (total PLC) was obtained by summing native PLC with occlusion PLC in each sample. As the first ring of xylem vessels (i.e. protoxylem) was always non-functional ( $>90 \%$ PLC), both in control and tiger-stripe stems, it was removed from the analysis.

219 We investigated whether native PLC, and occlusion PLC differed between control and esca tiger-stripe plants, using two independent generalized mixed linear models where plants were treated as a random effect. Proportional data (ranging from 0 to 1, dividing all PLC values by 100) was analyzed to fit a logit link function and binomial distribution as appropriate.

\section{Monitoring stem hydraulic properties over time}

Xylem integrity was monitored over time by measuring hydraulic properties in stems produced on the year of the experiment and collected on control and symptomatic plants along the season and during esca development. Specific hydraulic conductivity $\left(k_{s}\right)$ was measured on internodes sampled in the center of the collected stem by the gravity method (Sperry et al., 1988), and 
compared to its theoretical analog $\left(k_{t h}\right)$ calculated from xylem anatomical observations on the same internode or on the one below (see the method described below). When there are observed differences in $k_{s}$ among stems, comparisons with theoretical maximums $\left(k_{t h}\right)$ can show if lower $k_{s}$ values result from anatomical differences (i.e. different vessel size distributions) or by hydraulic failure (in the case of similar vessel size and density). If $k_{s}$ varies in unity with $k_{t h}$, differences in $k_{s}$ might result from anatomical differences (e.g. smaller $k_{s}$ are related to smaller vessels), otherwise $k_{s}$ variations are the consequence of hydraulic failure. Each method to measure $k_{s}, k_{t h}$, and to observe tyloses is described below.

Sampling started on June $19^{\text {th }}$ and finished on September $13^{\text {th }} 2019$ for a total of 10 sampling dates, 39 stems of the current year from 23 control-asymptomatic plants, and 49 stems of the current year from 17 symptomatic plants. We randomly sampled control plants and esca symptomatic plants all along the season through the evolution of esca symptoms, obtaining measurements from 14 weeks before until 10 weeks after symptom appearance. To explore the contribution of the experimental design to data analysis, we tested the effect of the year of uprooting (2018 and 2019), the position of the analyzed internode, and the week of the measurement (i.e. evolution during the season) on $k_{s}$ and $k_{t h}$ in control plants using separate generalized linear mixed model with normal distributions and the plant treated as a random variable (Table S1). A significant impact of the year of uproot was found for $k_{s}$ and $k_{t h}$ values in control plants (Table S1). This could have resulted from the more favorable conditions (i.e. climatic stability and nutrient availability) for the greenhouse grown vines (note that plants uprooted in 2017 were only esca symptomatic and were not included in this analysis). However, once $k_{s}$ and $k_{t h}$ are plotted together (Fig. S2), all the values lie on the same regression line without generating outlier values (smaller $k_{s}$ values correspond to smaller $k_{\text {th }}$ values independently of the uprooting year).

\section{Stem specific hydraulic conductivity $\left(\boldsymbol{k}_{s}\right)$}

$k_{s}$ measurements were performed on one internode per stem, located in the center of the collected $>1.5 \mathrm{~m}$ long stem, following Torres-Ruiz et al. (2012) gravity method. In the early morning, each stem was cut at the base under water to avoid air entrance in the stem, maintained under water and brought to the laboratory. Hydraulic conductivity measurements were always done before noon, in order to minimize the delay (never more than four hours) from the cut to the measure. In the laboratory, a representative internode between the 4th to the 10th internode from the base (i.e. in the center of the stem) was cut underwater with a clean razor blade, the 
261

262

263

264

265

266

267

268

269

270

271

272

273

274

275

276

277

278

279

280

281

282

283

284

285

286

287

288

ends wrapped in tape, and the internode was connected to a pipe system. A flow of $20 \mathrm{mM} \mathrm{KCl}$ solution passed through the sample from a reservoir to a precision electronic balance (AS220.R2, RADWAG, Radom, PL) recording the weight every 5 seconds using the WinWedge v3 5.0 software (TAL Technologies, Philadelphia, PA, USA). The solution was passed through the stem at four increasing pressures (ranging from 0.001 to $0.005 \mathrm{MPa}$ ), controlled by raising the source height. The average flow for each pressure step was determined after stabilization at a steady-state as the average of 10-15 measures. Hydraulic conductance, $k$ $\left[\mathrm{kg} \mathrm{s}^{-1} \mathrm{MPa}^{-1}\right]$ was obtained by the slope generated by the flow and the corresponding pressure. The linear relationship between flow and pressure obtained were always characterized by $\mathrm{R}^{2}>0.97$. Stem specific hydraulic conductivity, $k_{s}\left[\mathrm{~kg} \mathrm{~s}^{-1} \mathrm{MPa}^{-1} \mathrm{~m}^{-1}\right]$, was calculated as follows:

$$
\begin{gathered}
k_{S}=\frac{(k \times l)}{A} \\
A=\left(\left(\frac{d_{1}}{2}\right)^{2} \times \pi\right)-\left(\left(\frac{d_{2}}{2}\right)^{2} \times \pi\right)
\end{gathered}
$$

Where: $k$ is the hydraulic conductance, $l$ is the length of the sample, $A$ is the xylem area, $d_{l}$ is the external diameter of the debarked stem, and $d_{2}$ is the diameter of the central pith.

\section{Stem theoretical hydraulic conductivity $\left(k_{t h}\right)$, vessel anatomy, and tylose observation}

Just before hydraulic conductivity $\left(k_{s}\right)$ measurements, the lower internode was stored at $4{ }^{\circ} \mathrm{C}$ in $80 \%$ ethanol for analysis of xylem anatomy. When possible, the same internode of $k_{s}$ measurements was used for anatomical analysis and $k_{t h}$ estimations, otherwise the stored internode was used for the following protocol. $50 \mu \mathrm{m}$ thick slices were obtained using a GSL1 microtome (Gärtner et al., 2014). Slices were stained using a $0.5 \%$ safranin solution during 5 minutes, and then washed three to four times in ethanol (100\%). They were quickly soaked in xylene and mounted on microscope slides with Permount Mounting Medium (Electron Microscopy Science, Hatfield, PA, USA). Images were captured with a stereo microscope SMZ1270 (Nikon, France) mounted with a DS-Fi3 camera (Nikon, France). The theoretical conductivity of each vessel $\left(k_{\text {vessel }}\right)\left[\mathrm{kg} \mathrm{m} \mathrm{Mpa}^{-1} \mathrm{~s}^{-1}\right]$ was calculated using the Hagen-Poiseuille equation as described above.

Where $\varnothing$ is the equivalent circle diameter $[\mathrm{m}]$ (measured with ImageJ software), $\rho$ the density of water $\left[998.2 \mathrm{~kg} \mathrm{~m}^{-3}\right.$ at $\left.20^{\circ} \mathrm{C}\right]$, and $\eta$ the viscosity of water $\left[1.002 \times 10^{-9} \mathrm{MPa}\right.$ s at $\left.20^{\circ} \mathrm{C}\right] . k_{t h}$ 
of the stem $\left[\mathrm{kg} \mathrm{s}^{-1} \mathrm{~m}^{-1} \mathrm{Mpa}^{-1}\right]$ was then calculated by summing every $k_{\text {vessel }}$ in the xylem area (A) $\left[\mathrm{m}^{2}\right]:$

$$
k_{t h}=\frac{\sum k_{\text {vessel }}}{A}
$$

292 In the entire cross section of each sample, the physical presence (or absence) of tyloses in vessel 293 lumina was visually assessed.

294 Regarding the statistical analysis, stems were grouped in six different categories following their 295 esca symptomatology (as presented in Fig. 1A). We investigated whether $k_{s}, k_{t h}$, and total vessel density differed among these different categories, and how $k_{s}, k_{t h}$, and total vessel density differed between stems with and without tyloses (independently from leaf symptom presence), using independent mixed linear general models. The symptom / tylose category and the year of uprooting (since it had a significant impact on $k_{s}$ and $k_{t h}$ in control plants, Table S1) were entered as fixed effects, with the plant treated as a random effect since different stems were sometimes analyzed from the same plant (88 analyzed stems on 40 different plants). Total density and densities for each vessel diameter class were log-transformed prior to analysis to fit normality requirements. For the classes with no vessels (e.g. samples without vessel diameters above $160 \mu \mathrm{m}$ ), a minimal density of 0.0001 was assigned prior to $\log$ transformation. We investigated whether the frequency of symptomatic stems presenting tyloses changed with the symptom age (i.e. weeks between first symptom detection and $k_{s}$ measurements on the same plant) with a Chi-square test. The relationships between stem $k_{s}$ and $k_{t h}$ were tested using linear regression models. Finally, we investigated whether $k_{s}$ and $k_{t h}$ in control stems differed between plants with different symptom history records using independent mixed linear general models with the plant treated as a random effect.

\section{Fungal detection}

313 Detection and quantification of Phaeomoniella chlamydospora and Phaeoacremonium 314 minimum were performed using qPCR in a subsample of stems of the current year $(\mathrm{n}=28)$ and 315 perennial trunks $(\mathrm{n}=20$ plants) from the same symptomatic and control plants used for 316 hydraulic and anatomical measurements. All along the season, basal internodes, from the same 317 stems sampled for $k_{s}$ and $k_{t h}$ measurements, were directly placed in liquid nitrogen and stored 
at $-80^{\circ} \mathrm{C}$. At the end of the experiment, a subset of plants was cut at the base for trunk sampling. A $2 \mathrm{~cm}$ high section was cut with a sterilized hand saw. The bark was removed and the different tissues of each section (necrotic and apparently healthy wood) were separately collected using ethyl alcohol-sterilized shears in a sterile environment, and immediately placed in liquid nitrogen. All samples were ground in liquid nitrogen using a tissue lyser (Tissuelyser II, Qiagen, Germantown, MD, USA). DNA was extracted from $60 \mathrm{mg}$ of ground tissue using the Invisorb Spin Plant Mini Kit (Invitek GmbH, Berlin, Germany)according to the manufacturer's instructions. . Detection and quantification of P. chlamydospora and P. minimum (previously named $P$. aleophilum) DNA by qPCR (SYBR Green assays) was conducted using the primer sets PchQF (5'-CTCTGGTGTGTAAGTTCAATCGACTC-3')/PchQR CCATTGTAGCTGTTCCAGATCAG-3') and $\operatorname{PalQF}\left(5^{\prime}-\right.$ CCGGTGGGGTTTTTACGTCTACAG-3')/ PalQR(5'CGTCATCCAAGATGCCGAATAAAG-3') (Pouzoulet et al. 2013). The qPCR reactions proceeded in a final volume of $25 \mu \mathrm{l}$, and the reaction mixtures containing $2 \mu \mathrm{L}$ of DNA template, $12.5 \mu 1$ of $2 X$ SYBRGreen Quantitect Master Mix (Qiagen, Venlo, Netherlands), and each primer at a final concentration of $0.4 \mu \mathrm{M}$. Experiments were conducted with a $\mathrm{Mx} 3005 \mathrm{P}$ Real-Time PCR cycler using MxPro qPCR software (Agilent Technologies). The cycling program, as described in Pouzoulet et al. (2017), consisted of an initial denaturation step at $95^{\circ} \mathrm{C}$ for $15 \mathrm{~min}$, and 40 cycles of $15 \mathrm{~s}$ at $95^{\circ} \mathrm{C}$ (for denaturation) followed by $45 \mathrm{~s}$ at $62^{\circ} \mathrm{C}$ (for both annealing and extension). A melting analysis of $40 \mathrm{~min}$ from 60 to $95^{\circ}$ was performed to verify reaction's specificity and the absence of byproducts. Preparation and use of standard solutions for the absolute quantification of fungal DNA was realized following Pouzoulet et al. (2013) using ten-fold dilutions of fungal DNA extracts obtained from axenic cultures. Reaction efficiencies ranging from $90 \%$ and $95 \%$ with an $\mathrm{R}^{2}>0.99(\mathrm{n}=15)$ were obtained for both $\mathrm{PchQF} / \mathrm{R}$ and PalQF/R primer sets. The average amount of DNA was determined based on three technical replicates (standards and plates) with a detection threshold superior to $95 \%$ (i.e. at least three positive amplification out of three replicates) or otherwise discarded (i.e. pathogen DNA was considered absent). Pathogen DNA quantity (average value of three technical replicates, $\mathrm{fg} / \mu \mathrm{l})$ was normalized by the amount of total DNA (ng/ $\mu \mathrm{l})$, measured using a Qubit fluorometer. The results from each trunk sample (i.e. necrotic or apparently healthy wood) were averaged together in order to obtain one quantification per plant. We investigated whether the amount of fungal DNA (both for P. chlamydospora and for P. minimum) in trunks differed between symptomatic and control plants, and between control plants with different symptom 
351

352

353

354

355

356

357

358

359

360

361

362

363

364

365

366

367

368

369

370

371

372

373

374

375

376

377

378

history records, using generalized linear mixed model with a poisson distribution and a log likelihood function.

\section{Statistical analysis}

All data management and statistical tests were done in SAS software (SAS 9.4; SAS Institute). We used PROC GLIMMIX for generalized linear mixed models, PROC GLM for generalized linear models, PROC REG for regression analyses and PROC FREQ for frequency analyses (Chi-square test of independence). The normality of the response variables was tested using a Kolmogorov-Smirnov test (PROC UNIVARIATE) prior to analyses. Data were logtransformed (total density) or appropriate distributions (binomial, poisson) were fitted when appropriate.

\section{RESULTS}

\section{Esca leaf symptom expression within and across seasons}

Esca leaf symptoms were recorded in 20 out of the 58 plants followed in this study $(35 \%$, Fig. 1, Table 1). The number of symptomatic plants increased gradually with time, from the first symptom appearance in early June to the last in late September (Fig. 1). There was no effect of the plant history (previously asymptomatic pA, or previously symptomatic pS) on 2019 symptom expression $\left(\mathrm{n}=58, X^{2}=0.27, \mathrm{P}=0.60\right)$. On $20 \mathrm{pA}$ plants, six (30\%) expressed leaf symptoms in 2019 (Table 1). On 38 pS plants, fourteen (37\%) showed symptoms in 2019 (Table 1). However, pS plants expressed symptoms from June to the end of September, while pA plants showed leaf symptoms only in September.

\section{In vivo observations of esca symptomatic stems}

Xylem vessels of control and tiger-stripe stems were observed using three dimensional X-ray microCT scans in iohexol-fed samples (Fig. 2, 3, Table S2). As shown in Fig. 2, functional and non-functional vessels can be discriminated through the use of iohexol (functional vessels appear bright white, non functional vessels appear either black if air-filled or grey if occluded). 
We observed almost totally functional stems in all asymptomatic stems $(<20 \%$ total PLC, Fig. 2A-C), and 40\% of tiger-stripe stems (e.g. Fig. 2D-G). Higher levels of PLC ( $>20 \%$ total PLC, Fig $\mathrm{H}-\mathrm{M}$ ) were observed in the remaining tiger-stripe stems, with $40 \%$ of tiger-stripe stems exhibiting over 50\% total PLC (Fig. 2J-M). When the two components of PLC were disentangled, we observed that the level of native PLC remained low both in control $(6.5 \pm$ $2.6 \%)$ and in tiger-stripe $(12.2 \pm 2.9 \%)$ stems (Fig. 3A). Occlusion PLC values were virtually zero in control stems $(0.7 \pm 0.02 \%)$ while in tiger-stripe stems the mean occlusion PLC values was $27.5 \pm 8.2 \%$ (Fig. 3B). Nevertheless, the variability of occlusion PLC across tiger-stripe stems was very high, the values ranging from $0.3 \%$ to $72.9 \%$ (Fig. 2D-M, and $3 \mathrm{~B}$ ), and occlusion PLC was not correlated to symptom age $\left(n=10, F_{2,7}=0.19, P=0.83\right)$. Consequently, no statistical differences in native or occlusion PLC were found between control and tigerstripe stems (Fig. 3). When higher occlusion PLC was measured (Fig. 2H-M), occluded vessels could be organized either on one side of the stem (Fig 2J-L) or randomly distributed across the section (Fig 2H, 2I, 2M). In 90\% of symptomatic stems, we observed that the most external vessels were functional. Occlusions were present equally in all vessel diameter classes (Fig. S3).

Tylose development, stem specific $\left(k_{s}\right)$ and theoretical $\left(k_{t h}\right)$ hydraulic conductivity during esca leaf symptom formation

Tyloses were identified in the xylem vessels of certain tiger-stripe stems and throughout the temporal development of esca leaf symptoms, from the appearance of symptoms to 11 weeks after. All apoplectic stems and 62.5\% (15 of 24 analyzed stems) of esca tiger-stripe stems presented tyloses, while all other stems (control, asymptomatic or pre-symptomatic) did not contain these occlusions, even until one week before symptom development. In esca tigerstripe stems, tyloses were not related to specific plants, or to symptom age (i.e. on the same plant at the same moment, different symptomatic stems could present tyloses, or not, $\mathrm{n}=24$, $\left.X^{2}=7.47, \mathrm{P}=0.38\right)$.

Overall, no significant impact of esca symptoms was observed on $k_{s}$ (Fig. 4A), even if tigerstripe stems were divided between those with and without tyloses. Control stems presented a mean $( \pm \mathrm{SE}) k_{s}$ of $24.97 \pm 1.72 \mathrm{~kg} \mathrm{~s}^{-1} \mathrm{MPa}^{-1} \mathrm{~m}^{-1}$; all the stems without tyloses measured on symptomatic plants showed the same range of values as control stems (Fig 4A, Table 2): 26.04 
$410 \pm 4.71$ for asymptomatic before symptoms appearance, $30.32 \pm 4.26$ for pre-symptomatic 411 stems, $19.80 \pm 5.18$ for asymptomatic stems after symptom appearance on the plant, and 21.29

$412 \pm 5.40$ for tiger-stripe stems without tyloses. Stems with tyloses (tiger-stripe and apoplectic 413 stems) presented the lowest average $k_{s}$ values $\left(11.27 \pm 2.86\right.$ and $2.47 \pm 1.45 \mathrm{~kg} \mathrm{~s}^{-1} \mathrm{MPa}^{-1} \mathrm{~m}^{-1}$ 414 for tiger-stripe and apoplectic, respectively). Regarding $k_{t h}$, no significant impact of esca 415 symptoms was found (Fig. 4C, Table 2), all the values were in the same range, with average 416 values ranging from 70.44 (for tiger-stripe stems with tyloses) to 87.88 (for pre-symptomatic stems) $\mathrm{kg} \mathrm{s}^{-1} \mathrm{MPa}^{-1} \mathrm{~m}^{-1}$.

418 In order to further investigate the impact of esca on stem hydraulics, we explored the 419 relationship between individual stem $k_{s}$ and $k_{t h}$ in each symptom category (Fig. 4B, S4, Table 420 2). Significant relationships were found between $k_{s}$ and $k_{t h}$ in all groups except in asymptomatic 421 stems after symptom appearance and symptomatic stems with the physical presence of tyloses

422 (Fig. S4, Table 2). The slopes of regression curves between $k_{s}$ and $k_{t h}$ did not vary among groups in the absence of tyloses (slope values ranged between 0.3 and 0.4 , Table 2) while it was close to 0 in the presence of tyloses ( 0.17 for tiger-stripe and 0.04 for apoplectic stems). When $k_{s}$ and $k_{t h}$ are compared in the presence or absence of tyloses, we observed that $k_{s}$ was significantly lower when tyloses were present $\left(9.81 \pm 2.51 \mathrm{~kg} \mathrm{~s}^{-1} \mathrm{MPa}^{-1} \mathrm{~m}^{-1}\right.$ in the presence of tyloses vs $25.06 \pm 1.46 \mathrm{~kg} \mathrm{~s}^{-1} \mathrm{MPa}^{-1} \mathrm{~m}^{-1}$ in the absence of tyloses, Table 2, $\mathrm{n}=88, \mathrm{~F}_{1,49}=7.11$, $\mathrm{P}=0.01$ ) while $k_{t h}$ did not significantly differ. Stems without tyloses presented a strong correlation between $k_{s}$ and $k_{t h}$, while in the presence of tyloses this relationship was not significant (Table 2, Fig. 4B).

431 Total vessel density did not significantly differ between stem symptomatology (comparing all 432 the seven categories presented in Table 2), even when vessel density was partitioned by vessel 433 diameter classes (Fig. 4D).

Finally, we tested the impact of disease history (comparing pA and pS plants) on the hydraulic conductivity and xylem anatomy in control plants. There were no differences between longterm symptomatic $(\mathrm{pS})$ and long-term asymptomatic $(\mathrm{pA})$ plants in stem $k_{s}$, stem $k_{t h}$, or total vessel density (Table 3 ). 
The two vascular pathogens associated with esca (Phaeomoniella chlamydospora and Phaeoacremonium minimum) were never detected in stems of the current year while they were systematically detected in the perennial trunk of both control and symptomatic plants (Table 4). In trunks, a significantly higher quantity of fungal DNA was detected in tiger-stripe symptomatic plants than in controls (Table 4). We found 2.14- and 1.64-fold more of $P$. chlamydospora and P. minimum DNA in symptomatic trunks relative to controls. In control plants, different symptom history records impacted the quantity of fungal DNA detected by qPCR, for Phaeomoniella chlamydospora, and for Phaeoacremonium minimum. We found 1.65- and 2.84-fold more P. chlamydospora and P. minimum DNA in previously symptomatic trunks relative to previously asymptomatic trunks (Table 3 ).

\section{DISCUSSION}

Our results regarding the impact of esca on stem xylem integrity show that the presence of plant-derived tyloses induced hydraulic failure in $60 \%$ of symptomatic stems of the current year. Tyloses were only observed in symptomatic stems, and resulted in more than $50 \%$ PLC in $40 \%$ of the stems, unrelated to symptom age. We demonstrated that the presence of leaf symptoms during previous seasons had no impact on the likelihood of symptom appearance in the current year, or on stem hydraulic conductivity and xylem anatomy. Vascular fungi were never detected in the same organs as the tyloses (stems of the current year), and although they were present in trunks of both tiger-stripe and control plants, tiger-stripe plants showed higher quantities of fungal DNA. Among control plants that did not express symptoms in the year of the study, we found higher quantities of fungal DNA in trunks of those plants with a long-term history of symptom formation. Albeit xylem occlusions were not observed in the totality of tiger-stripe stems, they could amplify yield loss plant mortality, especially in the context of climate change as they impair water transport in a majority of symptomatic stems.

\section{In vivo xylem integrity observations and hydraulic vulnerability segmentation}

Using direct X-ray microCT imaging in esca symptomatic stems, we found that hydraulic conductivity loss was almost entirely associated with the presence of tyloses. Different studies have investigated the link between vascular pathogen development and hydraulic conductivity 
470

471

472

473

474

475

476

477

478

479

480

481

482

483

484

485

486

487

488

489

490

491

492

493

494

495

496

497

498

499

500

501

in stems (Collins et al., 2009; Lachenbruch and Zhao, 2019; Mensah et al., 2020). During biotic stresses, air embolisms have been shown to decrease hydraulic conductivity during bacterial leaf scorch disease (McElrone et al., 2003; 2008), Pierce's disease (Pérez-Donoso et al., 2016), and Pine wilt disease (Yazaki et al., 2018). In the case of fungal wilt diseases, the hydraulic conductivity loss was associated with nongaseous embolism (i.e. tyloses) at the point of pathogen inoculation (Guerard et al., 2000; Sallé et al., 2008; Beier et al., 2017; Mensah et al., 2020), or with canker presence in naturally infected stems (Lachenbruch and Zhao, 2019).

Using iohexol we were able to visually observe the exact spatial organization of functional vessels. Interestingly, in some symptomatic samples we found functional vessels surrounding the non-functional xylem (Fig. 2J-L), suggesting that the plant was able to preserve the more external vessels from occlusions or to form new functional vessels after the loss of conductivity. Moreover, the sectoriality of the occlusions observed in Fig. 2J-L was reminiscent of the sectoriality observed in the distributions of trunk necrosis, especially on the brown stripe necrosis appearing along the vasculature (Lecomte et al., 2012).

Comparing these results with our precedent study using the same technique in leaves, we showed that esca symptomatic leaves presented higher levels of occlusion PLC $(61 \pm 7 \%$ in midribs, and $54 \pm 9 \%$ in petioles, data from Bortolami et al., 2019) compared to stems (27 \pm 8 $\%$, occlusion PLC), suggesting hydraulic vulnerability segmentation (although PLC in leaves and stems were measured in different plants and years). The hydraulic segmentation theory relies on the fact that annual organs (i.e. leaves) are more vulnerable than perennial organs (i.e. stems) to drought induced air embolism (Tyree and Ewers, 1991). Grapevine is well known for exhibiting strong hydraulic vulnerability segmentation (Charrier et al., 2016; Hochberg et al., 2016; 2017). This is thought to be adaptive, where the higher vulnerability in leaves and petioles favors embolism formation and leaf shedding prior to embolism formation in stems, thus protecting the perennial organs. Our observations during esca pathogenesis demonstrate that, analogous to the hydraulic vulnerability segmentation theory, leaves appear more vulnerable to the formation of nongaseous embolism as well, which could mitigate the risk of hydraulic failure in perennial organs. From another perspective, the difference may not be a direct effect of the specific organ's vulnerability to nongaseous embolism, but a consequence of a difference in the accumulation of putative toxins and/or elicitors. Indeed, we confirmed here that esca leaf symptoms occur at a distance from the pathogen niche because vascular pathogens were never detected in stems of the current year, suggesting that the plant may 
502

503

504

505

506

507

508

509

510

511

512

513

514

515

516

517

518

519

520

521

522

523

524

525

526

527

528

529

530

531

532

transport a signal (i.e. toxins or elicitors) from the infected trunk up to the leaves. If the signal accumulates in leaves in a higher amount than it does in the stems (water potentials are more negative in leaves compared to stems), and stimulates occlusion formation, stems would then be secondarily affected.

\section{Hydraulic conductivity, tyloses, and vessel anatomy}

Tyloses could have different impacts, both positive and negative, during wilt disease pathogenesis: (i) tyloses contribute to pathogen resistance as they aim to seal off vessel lumens and impede pathogens spread throughout the host (CODIT model, Shigo, 1984). This is the case regarding the susceptibility of different species or varieties to specific pathogens (Jacobi and MacDonald, 1980; Ouellette et al., 1999; Clérivet et al., 2000; Et-Touil et al., 2005; Venturas et al., 2014; Park and Juzwik 2014; Rioux et al., 2018), in particular to Phaeomoniella chlamydospora, one of the pathogen associated with esca (Pouzoulet et al., 2017; 2020). (ii) In other studies, it has been shown that tyloses can exacerbate symptoms (Talboys, 1972): they cause a reduction in stem hydraulic conductivity, sometimes associated with a reduction in stomatal conductance in leaves and, in the most severe cases, wilting (Parke et al., 2007; Beier et al., 2017; Lachenbruch and Zhao, 2019, Mensah et al., 2020 during fungi development; Sun et al., 2013; Deyett et al., 2019 during Pierce's disease). Our results suggest that during esca tyloses might lead to symptom exacerbation. Esca has also been suggested to lead to a general reduction in xylem water transport and stomatal conductance (Ouadi et al., 2019), and tyloses could be a major contributor to these phenomena as during winter senescence (Salleo et al., 2002; Sun et al., 2008). However, when symptomatic stems have no tyloses ( $37 \%$ of the stems with tiger-stripe symptoms), esca leaf symptom formation seems to arise from within the leaf itself, and may not result from upstream hydraulic failure. Although tyloses were never detected in asymptomatic stems prior to the onset of leaf symptoms, the time sequence of tylose and leaf symptom development has still to be determined. Since both the microCT and anatomical observations visualize relatively narrow regions of the stems, tylose presence could have been underestimated (i.e. if there was additional tylose development up or downstream of the stem sections visualized). However, it should be pointed out that if significant underestimation were present we would expect some loss of conductivity even in internode sections from which we observed no tyloses in the sampled cross sections. At least when 
533

534

535

536

537

538

539

540

541

542

543

544

545

546

547

548

549

550

551

552

553

554

555

556

557

558

559

560

561

562

563

considering a single internode our direct hydraulic conductivity measurements do not support the hypothesis that tyloses were underestimated (Fig. 4B).

Xylem is the battleground between vascular pathogens and the plant's defense response (Yadeta and Thomma, 2013). Even if xylem vessel anatomy is less investigated, it could have a crucial role in plant resistance and response to vascular pathogens. For example, during Dutch elm wilt disease (due to Ophiostoma spp.) the most sensitive species and varieties present wider xylem vessels (Elgersma, 1970; Mcnabb et al., 1970; Solla and Gil 2002; Pita et al., 2018). Smaller vessels could occlude faster, sustaining a more efficient pathogen restriction (Venturas et al., 2014). Our results on xylem vessel anatomy suggest that stems with tyloses tend to present higher densities of small vessels, even if we did not observe any differences in total $k_{t h}$ values and microCT scans showed that occlusions appear randomly in every vessel size class (Fig. S3). It could be possible that tylose formation might be interfering with stem water relations reducing the carbohydrates available for plant growth, producing smaller vessels in stems of symptomatic plants. In contrast, artificial inoculations showed that xylem vessel diameter had a strong impact on esca-related vascular pathogen development (Pouzoulet et al., 2017; 2020), and in the kinetic of vessel occlusion in grapevine stems (Pouzoulet et al., 2019). The relationships between esca leaf symptoms, xylem anatomy, and tylose presence should be studied in detail in trunks, where vascular pathogens are present, and among different grapevine varieties and rootstocks as they are known to show different susceptibility to symptom expression.

\section{Long-term consequences of esca on leaf symptom expression and stem hydraulic integrity}

In field surveys, esca leaf symptoms are often randomly distributed spatially throughout vineyards and are not consistent from season to season in individual vines (Mugnai et al., 1999; Surico et al., 2000; Marchi et al., 2006; Guerin-Dubrana et al., 2013; Li et al., 2017). However, esca-related vine death is strongly related to leaf symptoms as death is usually observed following a year with symptom expression (Guerin-Dubrana et al., 2013). In agreement with these field studies, we observed similar percentages of symptomatic plants between those that had already expressed esca symptoms in the past (from one to seven consecutive years, pS plants), and those that had never expressed symptoms over the past seven years (pA plants). However, we also found that pS plants expressed symptoms earlier in the season than $\mathrm{pA}$ 
564

565

566

567

568

569

570

571

572

573

574

575

576

577

578

579

580

581

582

583

584

585

586

587

588

589

590

591

592

593

594

plants, suggesting that symptoms might require more time to develop in pA plants. We did not find any significant differences in $k_{s}$ and $k_{t h}$ values between plants with contrasted long-term symptom history. This result suggests that esca leaf symptoms may have xylem anatomical consequences within the year of expression by the production of tyloses, but not across seasons. Moreover, we showed that DNA pathogen amount (Phaeoacremonium minimum and Phaeomoniella chlamydospora) depends on the symptom expression in the season of sampling, and on the long-term symptom history. Altogether, these results suggest that a higher amount of vascular fungi in the trunk represents a higher risk in reproducing leaf symptoms, and consequently, a higher risk of plant death.

\section{Hydraulic failure and esca leaf symptom pathogenesis}

Our results showed that, even if esca-related stem occlusion was extremely variable, $40 \%$ of the microCT analyzed stems presented a total PLC greater than 50\%. Under drought conditions alone, studies suggest that grapevines are not able to recover in the current season from PLC greater than $50 \%$ in stems (Charrier et al., 2018). Thus, to what extent these levels of escainduced hydraulic failure compromise future vine performance, and/or increase the likelihood of developing esca leaf symptoms in the future remains an open question.

We showed that, similarly to visual leaf symptoms, tyloses in stems were generated at a distance from the pathogen niche in the trunk. Comparing our results with Bortolami et al. (2019), we show that the PLC due to the occlusions (hydraulic failure) observed using microCT in leaves was on average twice higher than the PLC observed in stems in the present work. We could hypothesize that, following pathogen activities in the trunk, a signal passing through the xylem network and stimulating tyloses, first accumulates in leaves and then affects the stems. However, the exact signal and action remain unknown, as we showed that the presence of tyloses depended upon given symptomatic stems rather than symptomatic plants (i.e. two stems in the same plant, with same tiger-stripe symptoms, sampled at the same moment, could or could not present tyloses).

We showed that there were no differences in symptom expression, nor in the stem hydraulic properties, regarding the long-term symptom history. We can conclude that the processes that generate tiger-stripe symptoms are largely restricted to the current year of the symptom expression. However, in plants expressing symptoms for the first time according to our disease 
595

596

597

598

599

600

601

602

603

604

605

606

607

608

609

610

611

612

613

614

615

616

617

618

619

620

621

622

623

624

625

626

record, these processes could require more time, as they showed symptoms only late in the season. The presence of occlusion, leading to hydraulic failure in stems, could exacerbate leaf symptom expression in the following seasons, possibly contributing to death. We could speculate that a stem expressing extensive hydraulic failure could be more prone to express symptoms in the following year or, in the worst cases, to die. If the level of hydraulic failure could affect the stem mortality in the following year, the choice of stems with a complete absence of failure during the winter pruning could reduce the impact of esca in vineyards. The pruning practices are known to impact the course of infection and leaf symptom development and it has been shown that trunk renewal could be an effective management practice to prevent grapevine trunk diseases in the vineyard (Travadon et al. 2016, Kaplan et al. 2016, Gramaje et al. 2018). In addition, the presence of occlusions could also amplify plant susceptibility to drought-induced hydraulic failure, enhancing the risk of plant mortality in the field as suggested by McDowell et al. (2008). It could be speculated that a decrease in soil water potential or a high evaporative demand, concomitant to esca-induced hydraulic failure, could embolize the remaining functional xylem vessels stopping the water flow and desiccating plant tissues (this could be the case in apoplectic plants for example). In perspective, future studies should investigate the link between pathogen activities and occlusion development, especially in trunks, and the subsequent hydraulic failure consequences on whole plant physiology.

\section{SUPPORTING INFORMATION}

The following Supporting Information is available for this article:

Fig. S1. Two-dimensional reconstruction of longitudinal cross sections from X-ray microCT volumes of grapevine stems.

Fig. S2. Relationship between $k_{s}$ and $k_{t h}$ in control plants.

Fig. S3. Vessel density and percentage of occluded vessels in tiger-stripe stems for different vessel diameter classes.

Fig. S4. Relationships between $k_{s}$ and $k_{t h}$ in each stem symptom category.

Table S1. Effect of year of uprooting, internode analyzed, and sampling date on $k_{s}$ and $k_{t h}$ in control stems.

Table S2. Calculated theoretical hydraulic conductivity $\left(k_{t h} \%\right)$, and hydraulic conductivity loss (PLC \%) from X-ray microCT volumes of intact grapevine stems. 


\section{DATA AVAILABILITY STATEMENT}

628

Raw datasets are available in the INRAE dataverse: Bortolami, Giovanni; Farolfi, Elena; Badel,

629 Eric; Burlett, Regis; Cochard, Herve; Ferrer, Nathalie; King, Andrew; Lamarque, Laurent J.;

630 Lecomte, pascal; Marchesseau-Marchal, Marie; Pouzoulet, Jerome; Torres-Ruiz, Jose M.;

631 Trueba, Santiago; Delzon, Sylvain; Gambetta, Gregory A.; Delmas, Chloe E.L., 2021, "Raw

632 data for the paper "Seasonal and long-term consequences of esca on grapevine stem xylem 633 integrity"'", https://doi.org/10.15454/U9KJEW, Portail Data INRAE, V1.

634

635

\section{ACKNOWLEDGMENTS}

636 We thank the experimental teams of UMR SAVE and UMR EGFV (Bord'O platform, INRAE, 637 Bordeaux, France) and the SOLEIL synchrotron facility (beamline PSICHE) for providing the 638 materials and logistics. Specifically, we thank Jérôme Jolivet and Sebastien Gambier (UMR 639 SAVE) for providing technical knowledge and support for plant transplantation and 640 maintenance. This work was supported by the French Ministry of Agriculture, Agrifood, and 641 Forestry (FranceAgriMer and CNIV) within the PHYSIOPATH project (program Plan 642 National Dépérissement du Vignoble, 22001150-1506) awarded to C.E.L.D., and program 643 Investments for the Future (ANR-10-EQPX-16, XYLOFOREST).

644

645

646 AUTHOR CONTRIBUTIONS

647 C.E.L.D., G.A.G., G.B., and S.D. designed the experiments;

648 E.F., G.A.G., S.D., E.B., R.B., H.C., A.K., L.J.L., J.M.T.-R., S.T. participated in synchrotron 649 campaigns;

650 G.B., C.E.L.D., E.F., and N.F. conducted the esca symptom notations;

651 G.B., M.M.-M., and N.F. conducted the histological observations;

652 E.F. conducted the hydraulic conductivity measurements and participated to data analyses;

653 N.F., and J.P., conducted the pathogen detection;

654 G.B. analyzed the microCT, optical images, and analyzed the data;

655 P.L. provided data on disease history of the plants;

656 G.B., C.E.L.D., and G.A.G. wrote the article;

657 all authors edited and agreed on the last version of the article

658 


\section{REFERENCES}

Akpaninyang FE, Opara EU. 2017. The Influence of Toxins in Disease Symptom Initiation in Plants: A Review. Journal of Agriculture and Sustainability 10, 29-52.

Aleemullah M., Walsh K. 1996. Australian papaya dieback: Evidence against the calcium deficiency hypothesis and observations on the significance of laticifer autofluorescence. Australian Journal of Agricultural Research 47, 371-385.

Alvindia DG, Gallema FLM. 2017. Lasiodiplodia theobromae causes vascular streak dieback (VSD)-like symptoms of cacao in Davao Region, Philippines. Australasian Plant Disease Notes 12, 54.

Anderegg WRL, Kane JM, Anderegg LDL. 2013. Consequences of widespread tree mortality triggered by drought and temperature stress. Nature Climate Change 3, 30-36.

Anderegg WRL, Klein T, Bartlett M, Sack L, Pellegrini AFA, Choat B, Jansen S. 2016. Meta-analysis reveals that hydraulic traits explain cross-species patterns of drought-induced tree mortality across the globe. Proceedings of the National Academy of Sciences 113, 50245029 .

Andolfi A, Mugnai L, Luque J, Surico G, Cimmino A, Evidente A. 2011. Phytotoxins Produced by Fungi Associated with Grapevine Trunk Diseases. Toxins 3, 1569-1605.

Beckman CH, Roberts EM. 1995. On the Nature and Genetic Basis for Resistance and Tolerance to Fungal Wilt Diseases of Plants. Advances in Botanical Research 21, 35-77.

Beier GL, Held BW, Giblin CP, Cavender-Bares J, Blanchette RA. 2017. American elm cultivars: Variation in compartmentalization of infection by Ophiostoma novo-ulmi and its effects on hydraulic conductivity. Forest Pathology 47, 1-11.

Bettenfeld P, Fontaine F, Trouvelot S, Fernandez O, Courty P-E. 2020. Woody Plant Declines. What's Wrong with the Microbiome? Trends in Plant Science 25, 381-394.

Bonsen KJM, Kučera LJ. (1990). Vessel Occlusions in Plants: Morphological, Functional and Evolutionary Aspects. IAWA Journal 11, 393-399. 
Bortolami G, Gambetta GA, Delzon S, et al. (2019). Exploring the Hydraulic Failure Hypothesis of Esca Leaf Symptom Formation. Plant Physiology 181, 1163-1174.

Brown AA, Lawrence DP, Baumgartner K. 2020. Role of basidiomycete fungi in the grapevine trunk disease esca. Plant Pathology 69, 205-220.

Cailleret M, Jansen S, Robert EMR, et al. 2017. A synthesis of radial growth patterns preceding tree mortality. Global Change Biology 23, 1675-1690.

Charrier G, Delzon S, Domec J-C, et al. 2018. Drought will not leave your glass empty: Low risk of hydraulic failure revealed by long-term drought observations in world's top wine regions. Science Advances 4, 1-9.

Charrier G, Torres-Ruiz JM, Badel E, et al. 2016. Evidence for Hydraulic Vulnerability Segmentation and Lack of Xylem Refilling under Tension. Plant Physiology 172, 1657-1668.

Claverie M, Notaro M, Fontaine F, Wery J. 2020. Current knowledge on Grapevine Trunk Diseases with complex etiology: A systemic approach. Phytopathologia Mediterranea 59, 2953.

Clérivet A, Déon V, Alami I, Lopez F, Geiger J-P, Nicole M. 2000. Tyloses and gels associated with cellulose accumulation in vessels are responses of plane tree seedlings $($ Platanus $\times$ acerifolia) to the vascular fungus Ceratocystis fimbriata $\mathrm{f}$. Sp platani. Trees 15 , 25-31.

Cloete M, Mostert L, Fischer M, Halleen F. 2015. Pathogenicity of South African Hymenochaetales taxa isolated from esca-infected grapevines. Phytopathologia Mediterranea 54, 368-379.

Collins BR, Parke JL, Lachenbruch B, Hansen EM. 2009. The effects of Phytophthora ramorum infection on hydraulic conductivity and tylosis formation in tanoak sapwood. Canadian Journal of Forest Research 39, 1766-1776.

Czemmel S, Galarneau ER, Travadon R, McElrone AJ, Cramer GR, Baumgartner K. 2015. Genes expressed in grapevine leaves reveal latent wood infection by the fungal pathogen Neofusicoccum parvum. PloS one 10, e0121828. 
Desprez-Loustau M-L, Marçais B, Nageleisen L-M, Piou D, Vannini A. 2006. Interactive effects of drought and pathogens in forest trees. Annals of Forest Science 63, 597-612.

Deyett E, Pouzoulet J, Yang J-I, Ashworth VE, Castro C, Roper MC, Rolshausen PE. 2019. Assessment of Pierce's disease susceptibility in Vitis vinifera cultivars with different pedigrees. Plant Pathology 68, 1079-1087.

De Micco V, Balzano A, Wheeler EA, Baas P. 2016. Tyloses and gums: A review of structure, function and occurrence of vessel occlusions. IAWA Journal 37, 186-205.

Elgersma DM. 1970. Length and diameter of xylem vessels as factors in resistance of elms to Ceratocystis ulmi. Netherlands Journal of Plant Pathology 76, 179-182.

Eskalen A, Stouthamer R, Lynch SC, Rugman-Jones PF, Twizeyimana M, Gonzalez A, Thibault T. 2013. Host Range of Fusarium Dieback and Its Ambrosia Beetle (Coleoptera : Scolytinae) Vector in Southern California. Plant Disease 97, 938-951.

Et-Touil A, Rioux D, Mathieu FM, Bernier L. 2005. External symptoms and histopathological changes following inoculation of elms putatively resistant to Dutch elm disease with genetically close strains of Ophiostoma. Canadian Journal of Botany 83, 656-667.

Fallon B, Yang A, Lapadat C, Armour I, Juzwik J, Montgomery RA, Cavender-Bares J. 2020. Spectral differentiation of oak wilt from foliar fungal disease and drought is correlated with physiological changes. Tree Physiology 40, 377-390.

Fradin EF, Thomma BPHJ. 2006. Physiology and molecular aspects of Verticillium wilt diseases caused by $V$. dahliae and V. albo-atrum. Molecular Plant Pathology 7, 71-86.

Gärtner H, Lucchinetti S, Schweingruber FH. 2014. New perspectives for wood anatomical analysis in dendrosciences: the GSL1-microtome. Dendrochronologia 32, 47-51.

Goberville E, Hautekèete N-C, Kirby RR, Piquot Y, Luczak C, Beaugrand G. 2016. Climate change and the ash dieback crisis. Scientific Reports 6 doi:10.1038/srep35303.

Gramaje D, Úrbez-Torres JR, Sosnowski MR. 2018. Managing Grapevine Trunk Diseases With Respect to Etiology and Epidemiology : Current Strategies and Future Prospects. Plant Disease 102, 12-39. 
Guérard N, Maillard P, Bréchet C, Lieutier F, Dreyer E. 2007. Do trees use reserve or newly assimilated carbon for their defense reactions? A 13C labeling approach with young Scots pines inoculated with a bark-beetle-associated fungus (Ophiostoma brunneo ciliatum). Annals of Forest Science 64, 601-608.

Guerin-Dubrana L, Labenne A, Labrousse JC, Bastien S, Rey P, Gegout-Petit A. 2013. Statistical analysis of grapevine mortality associated with esca or Eutypa dieback foliar expression. Phytopathologia Mediterranea 52, 276-288.

Guerin-Dubrana L, Fontaine F, Mugnai L. 2019. Grapevine trunk disease in European and Mediterranean vineyards: Occurrence, distribution and associated disease-affecting cultural factors. Phytopathologia Mediterranea 58, 49-71.

Hochberg U, Albuquerque C, Rachmilevitch S, Cochard H, David-Schwartz R, Brodersen CR, McElrone A, Windt CW. 2016. Grapevine petioles are more sensitive to drought induced embolism than stems: Evidence from in vivo MRI and microcomputed tomography observations of hydraulic vulnerability segmentation: Hydraulic vulnerability segmentation in grapevine. Plant, Cell \& Environment 39, 1886-1894.

Hochberg U, Windt CW, Ponomarenko A, Zhang Y-J, Gersony J, Rockwell FE, Holbrook NM. 2017. Stomatal Closure, Basal Leaf Embolism, and Shedding Protect the Hydraulic Integrity of Grape Stems. Plant Physiology 174, 764-775.

Jacobi WR, MacDonald WL. 1980. Colonization of resistant and susceptible oaks by Ceratocystis fagacearum. Phytopathology 70, 618-623.

Kaplan J, Travadon R, Cooper M, Hillis V, Lubell, Baumgartner K. 2016. Identifying economic hurdles to early adoption of preventative practices_ The case of trunk diseases in California winegrape vineyards. Wine Economics and Policy 15, 127-141.

King A, Guignot N, Zerbino P, et al. 2016. Tomography and imaging at the PSICHE beam line of the SOLEIL synchrotron. Review of Scientific Instruments 87, 093704.

Lachenbruch B, Zhao J-P. 2019. Effects of phloem on canopy dieback, tested with manipulations and a canker pathogen in the Corylus avellana/Anisogramma anomala host/pathogen system. Tree Physiology 39, 1086-1098. 
Lecomte P, Darrieutort G, Liminana J-M, Comont G, Muruamendiaraz A, Legorburu F-J, Choueiri E, Jreijiri F, El Amil R, Fermaud M. 2012. New Insights into Esca of Grapevine: The Development of Foliar Symptoms and Their Association with Xylem Discoloration. Plant Disease 96, 924-934.

Li S, Bonneu F, Chadoeuf J, Picart D, Gégout-Petit A, Guérin-Dubrana L. 2017. Spatial and Temporal Pattern Analyses of Esca Grapevine Disease in Vineyards in France. Phytopathology 107, 59-69.

Martin N, Vesentini D, Rego C, Monteiro S, Oliveira H, Ferreira RB. 2009. Phaeomoniella chlamydospora infection induces changes in phenolic compounds content in Vitis vinifera. Phytopathologia Mediterranea 48, 101-116.

Martín JA, Solla A, Ruiz-Villar M, Gil L. 2013. Vessel length and conductivity of Ulmus branches : Ontogenetic changes and relation to resistance to Dutch elm disease. Trees 27, 12391248 .

McDowell N, Pockman WT, Allen CD, et al. 2008. Mechanisms of plant survival and mortality during drought: Why do some plants survive while others succumb to drought? New Phytologist 178, 719-739.

McElrone AJ, Sherald JL, Forseth IN. 2003. Interactive effects of water stress and xylemlimited bacterial infection on the water relations of a host vine. Journal of Experimental Botany $54,419-430$.

McElrone AJ, Jackson S, Habdas P. 2008. Hydraulic disruption and passive migration by a bacterial pathogen in oak tree xylem. Journal of Experimental Botany 59, 2649-2657.

McNabb HS, Heybroek HM, Macdonald WL. 1970. Anatomical factors in resistance to Dutch elm disease. Netherlands Journal of Plant Pathology 76, 196-205.

Mensah JK, Sayer MAS, Nadel RL, Matusick G, Eckhardt LG. 2020. Physiological response of Pinus taeda L. trees to stem inoculation with Leptographium terebrantis. Trees 34, 869-880.

Mirone A, Brun E, Gouillart E, Tafforeau P, Kieffer J. 2014. The PyHST2 hybrid distributed code for high speed tomographic reconstruction with iterative reconstruction and a 
priori knowledge capabilities. Nuclear Instruments and Methods in Physics Research Section B: Beam Interactions with Materials and Atoms 324, 41-48.

Morales-Cruz A, Allenbeck G, Figueroa-Balderas R, Ashworth VE, Lawrence DP, Travadon R, Smith RJ, Baumgartner K, Rolshausen PE, Cantu D. 2018. Closed-reference metatranscriptomics enables in planta profiling of putative virulence activities in the grapevine trunk disease complex: Transcriptomics of pathogen communities. Molecular Plant Pathology $19,490-503$.

Mugnai L, Graniti A, Surico G. 1999. Esca (Black Measles) and Brown Wood-Streaking: Two Old and Elusive Diseases of Grapevines. Plant Disease 83, 404-418.

Ouadi L, Bruez E, Bastien S, Vallance J, Lecomte P, Domec J-C, Rey P. 2019. Ecophysiological impacts of Esca, a devastating grapevine trunk disease, on Vitis vinifera L. PloS one 14, 1-20.

Ouellette GB, Baayen RP, Simard M, Rioux D. 1999. Ultrastructural and cytochemical study of colonization of xylem vessel elements of susceptible and resistant Dianthus caryophyllus by Fusarium oxysporum f.sp. Dianthi. Canadian Journal of Botany 77, 644-663.

Paganin D, Mayo SC, Gureyev TE, Miller PR, Wilkins SW. 2002. Simultaneous phase and amplitude extraction from a single defocused image of a homogeneous object. Journal of Microscopy 206, 33-40.

Pandey S, Rishi RR, Jayaraj R, Giri K, Kumar R, Pandey A, Juwantha R, Madaan S, Bhandari MS. 2019. Fusarium equiseti is associated with the wilt and dieback of Aquilaria malaccensis in Northeast India. Forest Pathology 49, e12489.

Park J-H, Juzwik J. 2014. Ceratocystis smalleyi colonization of bitternut hickory and host responses in the xylem. Forest Pathology 44, 282-292.

Parke JL, Oh E, Voelker S, Hansen EM, Buckles G, Lachenbruch B. 2007. Phytophthora ramorum Colonizes Tanoak Xylem and Is Associated with Reduced Stem Water Transport. Phytopathology 97, 1558-1567.

Pearce RB. 1996. Antimicrobial defences in the wood of living trees. New Phytologist 132, 203-233. 
Pérez-Donoso AG, Lenhof JJ, Pinney K, Labavitch JM. 2016. Vessel embolism and tyloses in early stages of Pierce's disease. Australian Journal of Grape and Wine Research 22, 81-86.

Pita P, Rodríguez-Calcerrada J, Medel D, Gil L. 2018. Further insights into the components of resistance to Ophiostoma novo-ulmi in Ulmus minor: Hydraulic conductance, stomatal sensitivity and bark dehydration. Tree Physiology 38, 252-262.

Pouzoulet J, Mailhac N, Couderc C, Besson X, Daydé J, Lummerzheim M, Jacques A. 2013. A method to detect and quantify Phaeomoniella chlamydospora and Phaeoacremonium aleophilum DNA in grapevine-wood samples. Applied Microbiology and Biotechnology 97, 10163-10175.

Pouzoulet J, Scudiero E, Schiavon M, Rolshausen PE. 2017. Xylem Vessel Diameter Affects the Compartmentalization of the Vascular Pathogen Phaeomoniella chlamydospora in Grapevine. Frontiers in Plant Science 8, 1-13.

Pouzoulet J, Scudiero E, Schiavon M, Santiago LS, Rolshausen PE. 2019. Modeling of xylem vessel occlusion in grapevine. Tree Physiology 39, 1438-1445.

Pouzoulet J, Rolshausen PE, Charbois R, Chen J, Guillaumie S, Ollat N, Gambetta GA, Delmas CEL. 2020. Behind the Curtain of the Compartmentalization Process : Exploring How Xylem Vessel Diameter Impacts Vascular Pathogen Resistance. Plant, Cell \& Environment doi: $10.1111 /$ pce. 13848 .

Pratt RB, Jacobsen AL. 2018. Identifying which conduits are moving water in woody plants: A new HRCT-based method. Tree Physiology 38, 1200-1212.

Rioux D, Blais M, Nadeau-Thibodeau N, Lagacé M, DesRochers P, Klimaszewska K, Bernier L. 2018. First Extensive Microscopic Study of Butternut Defense Mechanisms Following Inoculation with the Canker Pathogen Ophiognomonia clavigignentijuglandacearum Reveals Compartmentalization of Tissue Damage. Phytopathology 108, 12371252.

Salle A, Ye H, Yart A, Lieutier F. 2008. Seasonal water stress and the resistance of Pinus yunnanensis to a bark-beetle-associated fungus. Tree Physiology 28, 679-687. 
Salleo S, Nardini A, Lo Gullo MA, Ghirardelli LA. 2002. Changes in stem and leaf hydraulics preceding leaf shedding in Castanea sativa L. Biologia plantarum 45, 227-234.

Schneider CA, Rasband WS, Eliceiri KW. 2012. NIH Image to ImageJ : 25 years of image analysis. Nature Methods 9, 671-675.

Shigo AL. 1984. Compartmentalization: A conceptual framework for understanding how trees grow and defend themselves. Annual Review of Phytopathology, 22, 189-214.

Sperry JS, Donnelly JR, Tyree MT. 1988. A method for measuring hydraulic conductivity and embolism in xylem. Plant, Cell \& Environment 11, 35-40.

Solla A, Gil L. 2002. Xylem vessel diameter as a factor in resistance of Ulmus minor to Ophiostoma novo-ulmi. Forest Pathology 32, 123-134.

Sun Q, Rost TL, Matthews MA. 2008. Wound-induced vascular occlusions in Vitis vinifera (Vitaceae) : Tyloses in summer and gels in winter. American Journal of Botany 95, 1498-1505.

Sun Q, Sun Y, Walker MA, Labavitch JM. 2013. Vascular Occlusions in Grapevines with Pierce's Disease Make Disease Symptom Development Worse. Plant Physiology 161, 15291541 .

Surico G, Marchi G, Ferrandino A, Braccini P, Mugnai L. 2000. Analysis of the spatial spread of esca in some Tuscan vineyards (Italy). Phytopathologia Mediterranea 39, 211-224.

Talboys PW. 1972. Resistance to Vascular Wilt Fungi. Proceedings of the Royal Society of London. Series B, Biological Science 181, 319-332.

Torres-Ruiz JM, Sperry JS, Fernández JE. 2012. Improving xylem hydraulic conductivity measurements by correcting the error caused by passive water uptake. Physiologia Plantarum $146,129-135$.

Travadon R, Lecomte P, Diarra B, Lawrence DP, Renault D, Ojeda H, Rey P, Baumgartner K. 2016. Grapevine pruning systems and cultivars influence the diversity of wood-colonizing fungi. Fungal Ecology 24 82-93.

Tyree MT, Sperry JS. 1989. Vulnerability of Xylem to Cavitation and Embolism. Annual Review of Plant Physiology and Plant Molecular Biology 40, 19-38. 
Tyree MT, Ewers FW. 1991. The hydraulic architecture of trees and other woody plants. New Phytologist 119, 345-360.

Úrbez-Torres JR, Peduto F, Vossen PM, Krueger WH, Gubler WD. 2013. Olive Twig and Branch Dieback: Etiology, Incidence, and Distribution in California. Plant Disease 97, 231244.

Venturas M, López R, Martín JA, Gascó A, Gil L. 2014. Heritability of Ulmus minor resistance to Dutch elm disease and its relationship to vessel size, but not to xylem vulnerability to drought. Plant Pathology 63, 500-509.

Yadeta KA, Thomma BPHJ. 2013. The xylem as battleground for plant hosts and vascular wilt pathogens. Frontiers in Plant Science 4 doi:10.3389/fpls.2013.00097.

Yazaki K, Takanashi T, Kanzaki N, Komatsu M, Levia DF, Kabeya D, Tobita H, Kitao M, Ishida A. 2018. Pine wilt disease causes cavitation around the resin canals and irrecoverable xylem conduit dysfunction. Journal of Experimental Botany 69, 589-602.

Zimmermann MH. 1979. The Discovery of Tylose Formation by a Viennese lady in 1845. IAWA Bulletin 2, 51-56. 


\section{TABLES}

Table 1. Esca leaf symptom observations over the experimental season on Vitis vinifera $\mathrm{cv}$ Sauvignon blanc.

\begin{tabular}{|c|c|c|c|}
\hline $\begin{array}{r}\text { Symptom notation } \\
\text { before } 2019\end{array}$ & All plants & $\begin{array}{l}\text { Previously } \\
\text { asymptomatic (pA) }\end{array}$ & $\begin{array}{l}\text { Previously } \\
\text { symptomatic (pS) }\end{array}$ \\
\hline \multicolumn{4}{|l|}{ Symptom notation in 2019} \\
\hline Esca-symptomatic & $35 \%(20 / 58)$ & $30 \%(6 / 20)$ & $37 \%(14 / 38)$ \\
\hline Control-asymptomatic & $65 \%(38 / 58)$ & $70 \%(14 / 20)$ & $63 \%(24 / 38)$ \\
\hline \multicolumn{4}{|c|}{$\begin{array}{l}\text { Plants are grouped by their symptom history: previously asymptomatic (pA, plants that have } \\
\text { never expressed leaf symptoms between } 2012 \text { and 2018) and previously symptomatic (pS, } \\
\text { plants that have expressed leaf symptoms at least once since 2012). Ratios present the number } \\
\text { of plants in each symptom category (esca-symptomatic or control-asymptomatic) over the total } \\
\text { number of plants of the category. }\end{array}$} \\
\hline
\end{tabular}


Table 2. Values for specific stem hydraulic conductivity $\left(k_{s}\right)$, theoretical stem hydraulic conductivity $\left(k_{t h}\right)$ and equations of regression lines between $k_{s}$ and $k_{t h}$ for control and esca symptomatic stems.

\begin{tabular}{|c|c|c|c|c|c|}
\hline Tyloses & Esca & $\begin{array}{c}k_{s} \\
{\left[\mathrm{~kg} \mathrm{~s}^{-1} \mathrm{~m}^{-1} \mathrm{MPa}^{-1}\right]}\end{array}$ & $\begin{array}{c}k_{t h} \\
{\left[\mathrm{~kg} \mathrm{~s}^{-1} \mathrm{~m}^{-1} \mathrm{MPa}^{-1}\right]}\end{array}$ & $\begin{array}{c}\mathbf{n} \\
\text { (stem - plant) }\end{array}$ & Regression \\
\hline \multirow{5}{*}{ Absence } & Control & $24.97 \pm 1.72$ & $78.36 \pm 4.51$ & $39-23$ & $\begin{array}{l}k_{s}=0.3 \times k_{t h}+1.6 \\
\mathrm{R}^{2}=0.61 \mathrm{P}<0.0001\end{array}$ \\
\hline & $\begin{array}{l}\text { Asymptomatic } \\
\text { before symptoms }\end{array}$ & $26.04 \pm 4.71$ & $74.75 \pm 11.80$ & $6-6$ & $\begin{array}{c}k_{s}=0.36 \times k_{t h}-0.94 \\
\mathrm{R}^{2}=0.82 \mathrm{P}=0.013\end{array}$ \\
\hline & Pre-symptomatic & $30.32 \pm 4.26$ & $87.88 \pm 8.54$ & $11-7$ & $\begin{array}{c}k_{s}=0.37 \times k_{t h}-1.9 \\
\mathrm{R}^{2}=0.54 \mathrm{P}=0.010\end{array}$ \\
\hline & $\begin{array}{l}\text { Asymptomatic } \\
\text { after symptoms }\end{array}$ & $19.80 \pm 5.18$ & $72.58 \pm 12.64$ & $5-2$ & $\begin{array}{l}k_{s}=0.33 \times k_{t h}-4 \\
\mathrm{R}^{2}=0.64 \mathrm{P}=0.104\end{array}$ \\
\hline & Esca (tiger-stripe) & $21.29 \pm 5.40$ & $72.85 \pm 10.41$ & $9-5$ & $\begin{array}{c}k_{s}=0.45 \times k_{t h}-11.26 \\
\mathrm{R}^{2}=0.74 \mathrm{P}=0.003\end{array}$ \\
\hline \multirow{2}{*}{ Presence } & Esca (tiger-stripe) & $11.27 \pm 2.86$ & $70.44 \pm 7.81$ & $15-5$ & $\begin{array}{c}k_{s}=0.17 \times k_{t h}-0.84 \\
\mathrm{R}^{2}=0.22 \mathrm{P}=0.077\end{array}$ \\
\hline & Esca (apoplectic) & $2.47 \pm 1.45$ & $74.80 \pm 33.48$ & $3-2$ & $\begin{array}{c}k_{s}=0.04 \times k_{t h}-0.2 \\
\mathrm{R}^{2}=0.68 \mathrm{P}=0.385\end{array}$ \\
\hline Absence & All & $25.06 \pm 1.46$ & $78.42 \pm 3.37$ & $70-37$ & $\begin{array}{c}k_{s}=0.34 \times k_{t h}-1.90 \\
\mathrm{R}^{2}=0.63 \mathrm{P}<0.0001\end{array}$ \\
\hline Presence & All & $9.81 \pm 2.51$ & $71.16 \pm 8.00$ & $18-7$ & $\begin{array}{c}k_{s}=0.12 \times k_{t h}-1.28 \\
\mathrm{R}^{2}=0.15 \mathrm{P}=0.117\end{array}$ \\
\hline
\end{tabular}

Values represent mean \pm SE. $\mathrm{n}=$ sample size, (including the number of analyzed stems andnumber of analyzed plants, respectively). See text and Fig. 4 for statistical analysis. A detailed esca symptom notation is provided in Fig. 1A. Bivariate plots of each regression are presented in Fig. S4. 
Table 3. Long-term impact of symptom presence (i.e. comparing plants with different disease history record) in control plants on specific stem hydraulic conductivity $\left(k_{s}\right)$, theoretical stem hydraulic conductivity $\left(k_{t h}\right)$, stem total vessel density, and amount of Phaeomoniella chlamydospora and Phaeoacremonium minimum DNA in trunks of plants without foliar symptoms.

\begin{tabular}{|c|c|c|c|}
\hline & $\begin{array}{c}\text { Previously } \\
\text { asymptomatic (pA) }\end{array}$ & $\begin{array}{c}\text { Previously } \\
\text { asymptomatic }(\mathrm{pS})\end{array}$ & $\begin{array}{c}\text { Type III Tests of } \\
\text { Fixed Effects (pA vs pS) }\end{array}$ \\
\hline$k_{s}\left[\mathrm{~kg} \mathrm{~s}^{-1} \mathrm{~m}^{-1} \mathrm{MPa}^{-1}\right]$ & $23.76 \pm 2.30$ & $26.54 \pm 2.61$ & $\mathrm{n}=39, \mathrm{~F}_{1,16}=1.19, \mathrm{P}=0.29$ \\
\hline$k_{t h}\left[\mathrm{~kg} \mathrm{~s}^{-1} \mathrm{~m}^{-1} \mathrm{MPa}^{-1}\right]$ & $72.22 \pm 4.85$ & $86.30 \pm 7.98$ & $\mathrm{n}=39, \mathrm{~F}_{1,16}=3.01, \mathrm{P}=0.10$ \\
\hline $\begin{array}{l}\text { total vessel density } \\
\quad\left[\text { count } \mathrm{mm}^{-2}\right]\end{array}$ & $57.28 \pm 4.03$ & $52.61 \pm 3.25$ & $\mathrm{n}=39, \mathrm{~F}_{1,16}=0.72, \mathrm{P}=0.41$ \\
\hline $\begin{array}{l}\text { P. chlamydospora } \\
{\left[\mathrm{pg} \mathrm{ng}^{-1}\right]}\end{array}$ & $6.14 \pm 1.90$ & $10.15 \pm 3.41$ & $\begin{array}{c}\mathrm{n}=13, \mathrm{~F}_{1,11}=5900.06, \\
\mathrm{P}<\mathbf{0 . 0 0 0 1}\end{array}$ \\
\hline $\begin{array}{l}\text { P. minimum }[\mathrm{pg} \mathrm{ng} \\
\left.{ }^{1}\right]\end{array}$ & $9.27 \pm 6.97$ & $26.40 \pm 13.83$ & $\mathrm{n}=13, \mathrm{~F}_{1,11}=51014, \mathrm{P}<0.00$ \\
\hline
\end{tabular}

Values represent means \pm SE. Pathogen quantification was estimated as: pg fungal DNA $\mathrm{ng}^{-1}$ total DNA. Statistical tests used are individual generalized linear mixed models to compare pA vs pS plants (fixed effect) with the individual plants entered as a random effect in the models and the year of uprooting as a co-variable (fixed effect). Statistically significant results $(\mathrm{P}<0.05)$ are shown in bold. 
Table 4. Quantification by qPCR of Phaeomoniella chlamydospora and Phaeoacremonium minimum DNA in stems and trunks of different esca symptomatology.

\begin{tabular}{|c|c|c|c|c|}
\hline Organ & Esca & $\mathbf{n}$ & P. chlamydospora $\left[\mathrm{pg} \mathrm{\textrm {ng } ^ { - 1 } ]}\right.$ & P. minimum $\left[\mathrm{pg} \mathrm{ng}^{-1}\right]$ \\
\hline \multirow{6}{*}{ Stem } & Control & 8 & 0 & 0 \\
\hline & Pre-symptomatic & 3 & 0 & 0 \\
\hline & $\begin{array}{l}\text { Asymptomatic } \\
\text { (after symptoms) }\end{array}$ & 3 & 0 & 0 \\
\hline & $\begin{array}{c}\text { Tiger-stripe } \\
\text { (without tyloses) }\end{array}$ & 4 & 0 & 0 \\
\hline & $\begin{array}{c}\text { Tiger-stripe } \\
\text { (with tyloses) }\end{array}$ & 8 & 0 & 0 \\
\hline & Apoplectic & 2 & 0 & 0 \\
\hline \multirow{2}{*}{ Trunk } & Control & 13 & $7.37 \pm 1.67(12 / 13)^{*}$ & $14.54 \pm 6.51(12 / 13)^{*}$ \\
\hline & Symptomatic & 7 & $15.80 \pm 3.12(7 / 7)^{*}$ & $23.90 \pm 8.82(7 / 7)^{*}$ \\
\hline
\end{tabular}

Pathogen quantification was estimated as: pg fungal DNA per ng total DNA.Values represent means $\pm \mathrm{SE}, \mathrm{n}=$ sample size. Trunks of symptomatic plants presented higher amount of both $P$. chlamydospora and $P$. minimum, compared to control $\left(\mathrm{n}=20, \mathrm{~F}_{1,18}=29806.11 .25, \mathrm{P}<0.0001\right.$ and $\mathrm{n}=20, \mathrm{~F}_{1,18}=21925.4, \mathrm{P}<0.0001$, respectively). See text for statistical methods. 
bioRxiv preprint doi: https://doi.org/10.1101/2020.09.07.282582; this version posted March 10,2021 . The copyright holder for this preprint (which was not certified by peer review) is the author/funder, who has granted bioRxiv a license to display the preprint in perpetuity. It is made available under aCC-BY-NC 4.0 International license.

\section{FIGURES}




\section{Esca symptom notation}

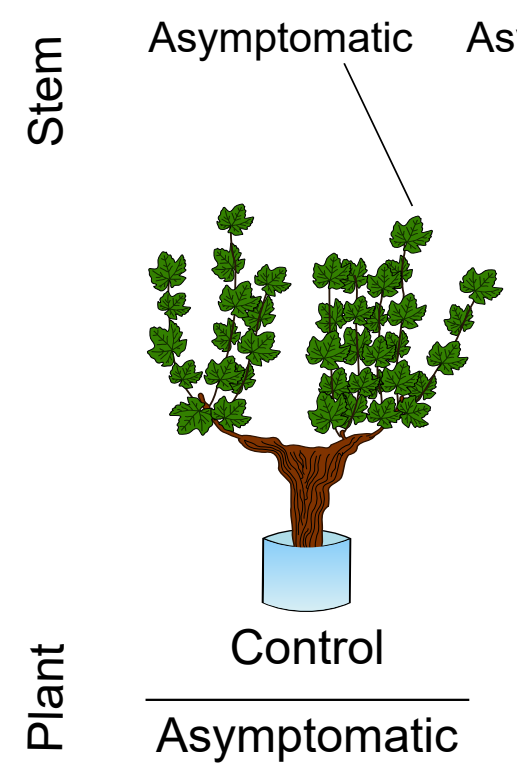

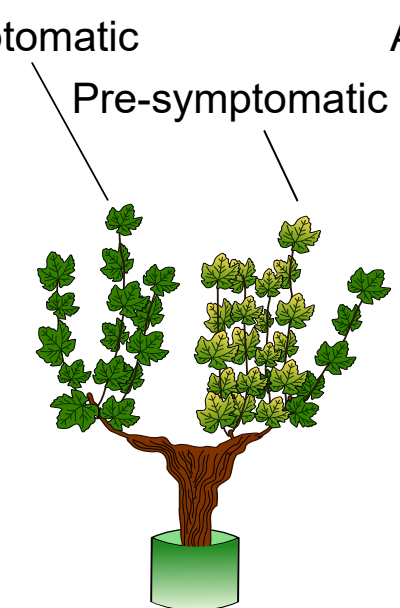

Before symptoms

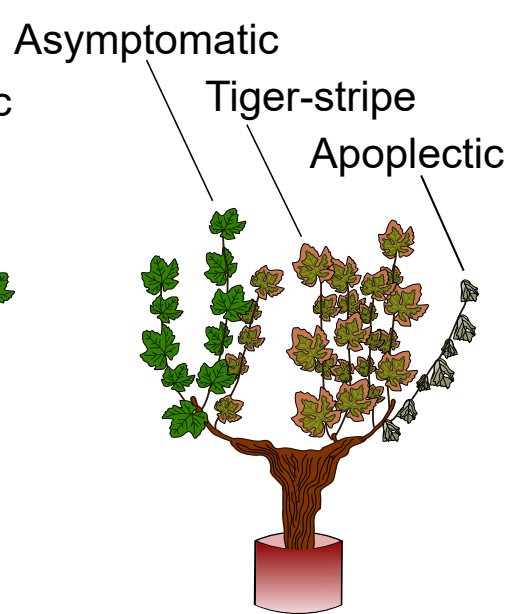

After symptoms

\section{Symptomatic}
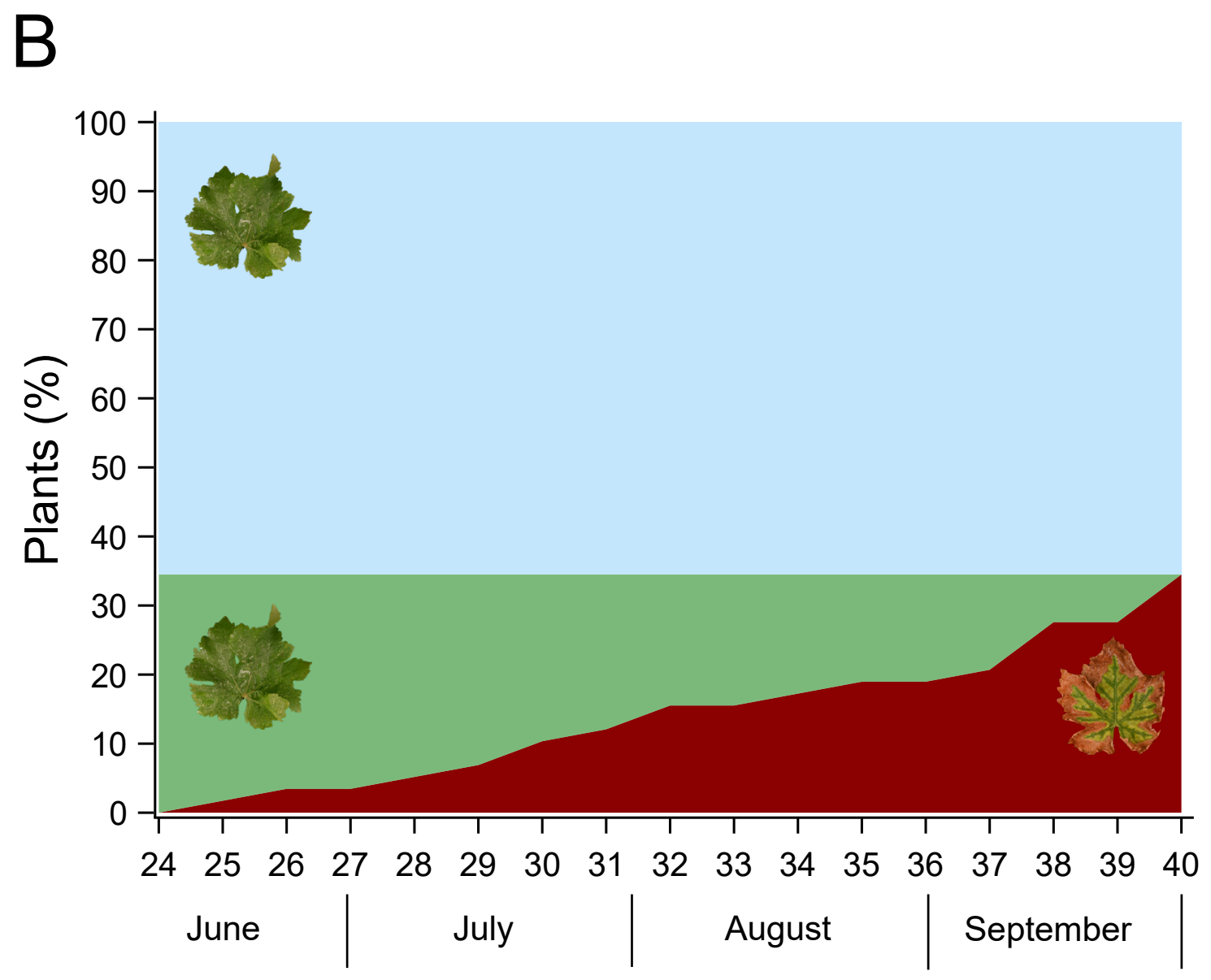

\section{Week of the year}

Fig. 1. Representation of esca symptom notation during the experimental season. (A) Single stems could be noted as esca asymptomatic, pre-symptomatic, tiger-stripe, or apoplectic. Whole plants have been noted as control (asymptomatic from June to October) or symptomatic (with tiger-stripe symptoms at the end of the season). (B) Proportion of plants in each symptom category over the experimental season $(\mathrm{n}=58)$. The blue area corresponds to control plants, green area to esca symptomatic plants before symptom appearance, and red area to esca symptomatic plants. 
bioRxiv preprint doi: https://doi.org/10.1101/2020.09.07.282582; this version posted March 10, 2021. The copyright holder for this preprint

(which was not certified by peer review) is the author/funder, who has granted bioRxiv a license to display the preprint in perpetuity. It is made available under aCC-BY-NC 4.0 International license.
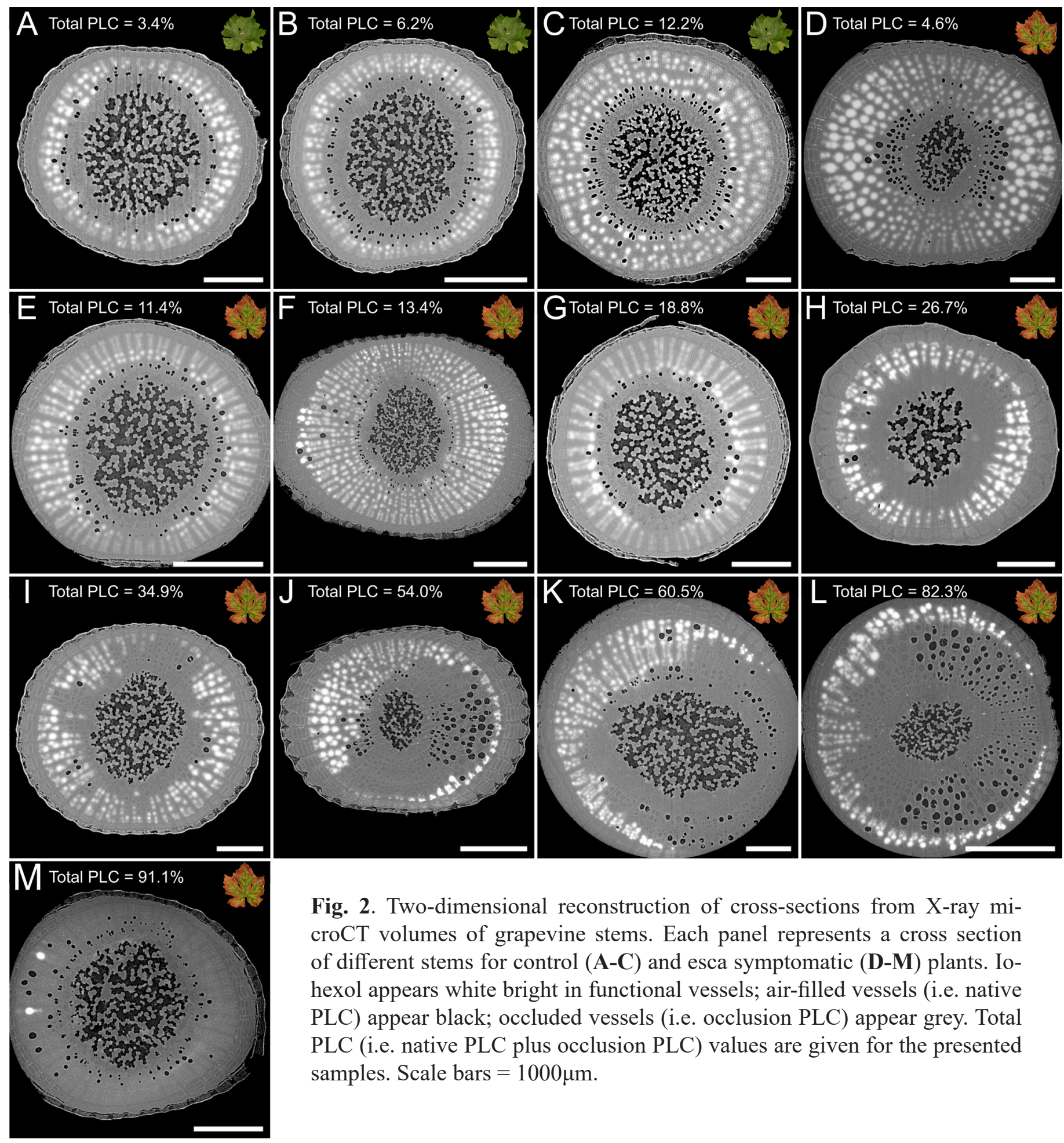

Fig. 2. Two-dimensional reconstruction of cross-sections from X-ray microCT volumes of grapevine stems. Each panel represents a cross section of different stems for control (A-C) and esca symptomatic (D-M) plants. Iohexol appears white bright in functional vessels; air-filled vessels (i.e. native PLC) appear black; occluded vessels (i.e. occlusion PLC) appear grey. Total PLC (i.e. native PLC plus occlusion PLC) values are given for the presented samples. Scale bars $=1000 \mu \mathrm{m}$. 


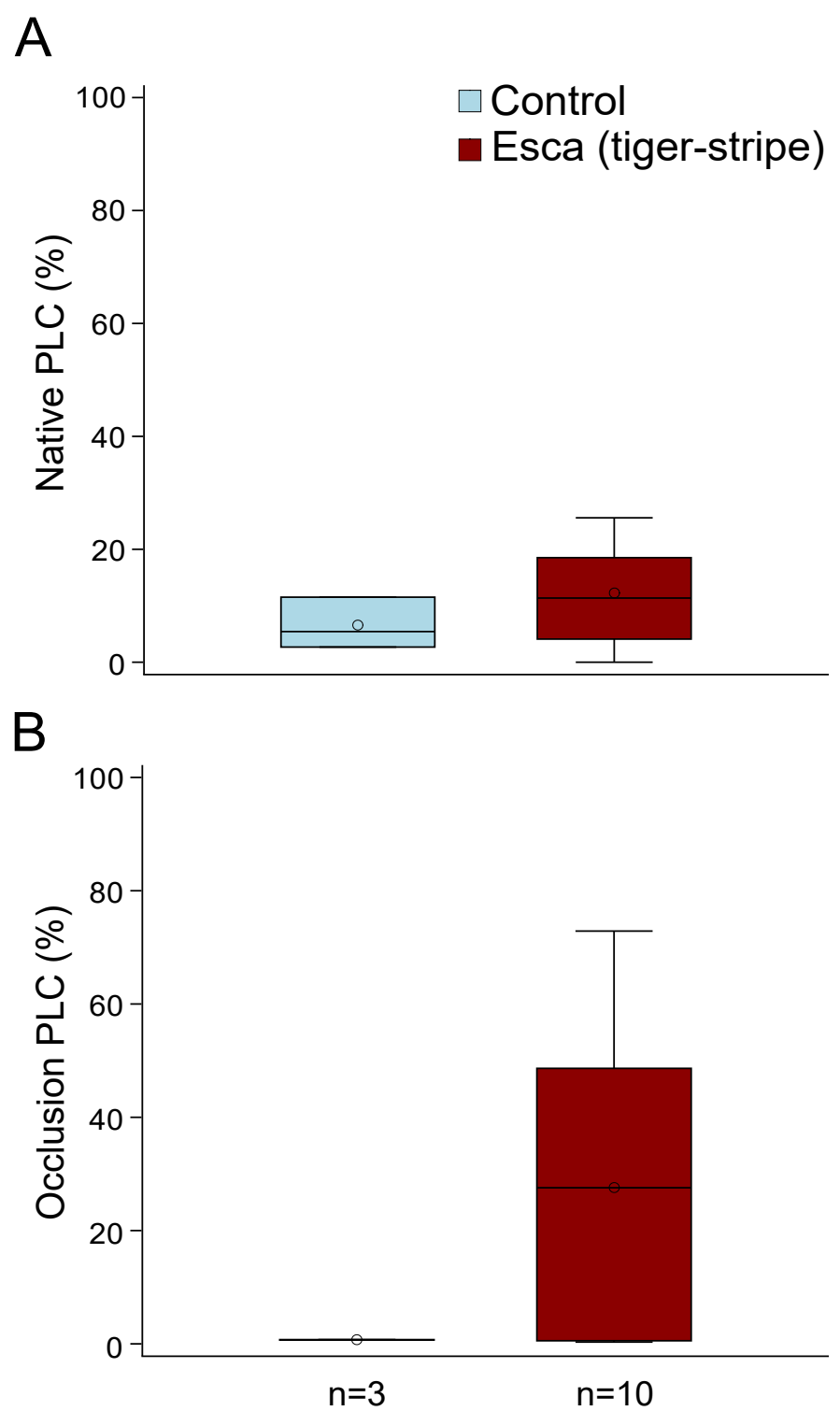

Fig. 3. (A) Mean values of native PLC in control (blue) and esca tiger-stripe (red) stems of grapevine plants using $\mathrm{X}$-ray microCT imaging. Differences were not significant $\left(\mathrm{n}=13, \mathrm{~F}_{1,9}=0.07, \mathrm{P}=0.79\right)$. (B) Mean values of occlusion PLC in control (blue) and esca tiger-stripe (red) stems of grapevine plants using X-ray microCT imaging. Differences were not significant $\left(\mathrm{n}=13, \mathrm{~F}_{1,9}=0.33, \mathrm{P}=0.58\right)$. Boxes and bars show the median, quartiles and extreme values, circles show mean values. $\mathrm{N}$ represents the sample size (number of analyzed stems) for each group. 
bioRxiv preprint doi: https://doi.org/10.1101/2020.09.07.282582; this version posted March 10, 2021. The copyright holder for this preprint (which was not certified by peer review) is the author/funder, who has granted bioRxiv a license to display the preprint in perpetuity. It is made available under aCC-BY-NC 4.0 International license.

A

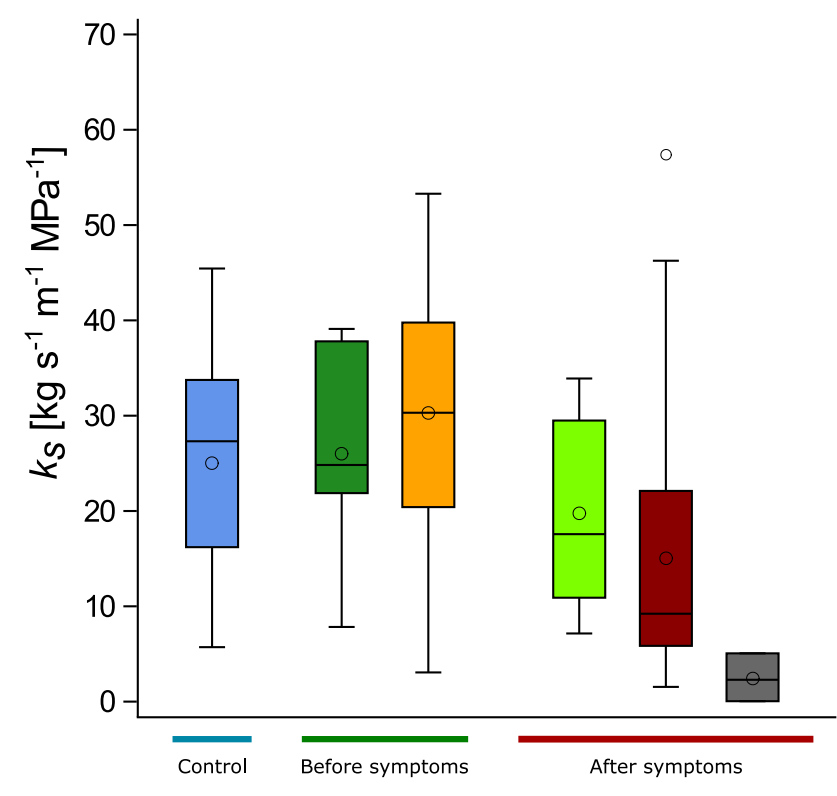

C

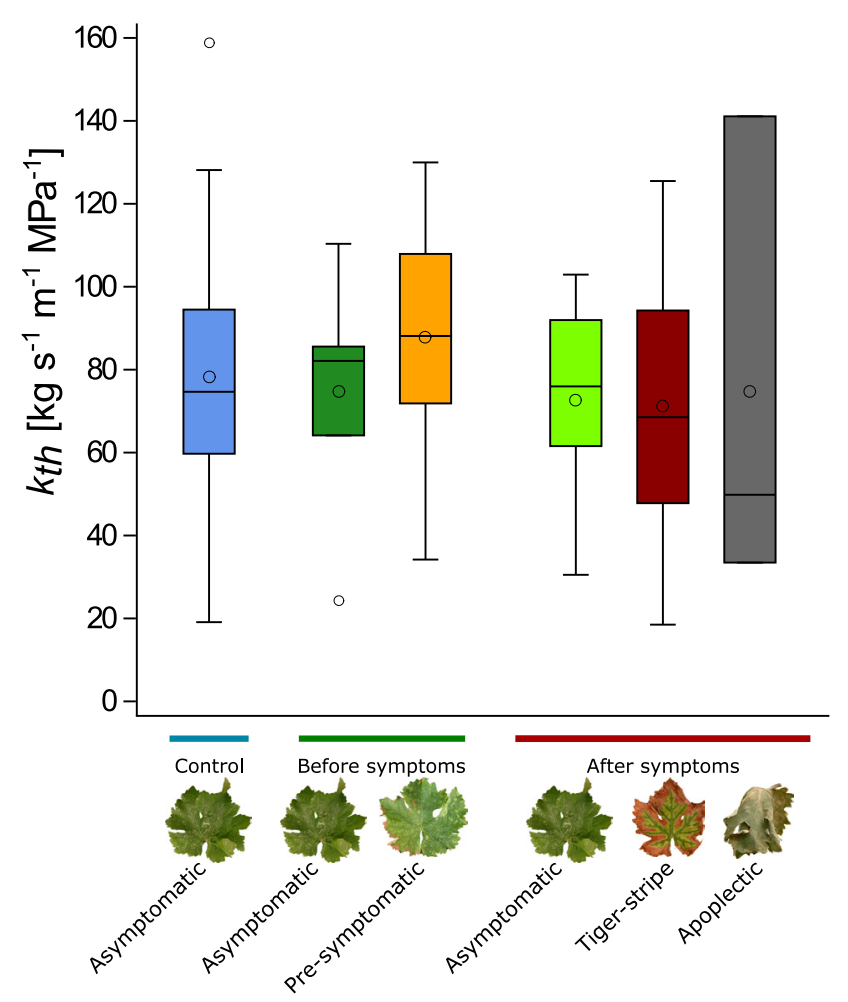

B
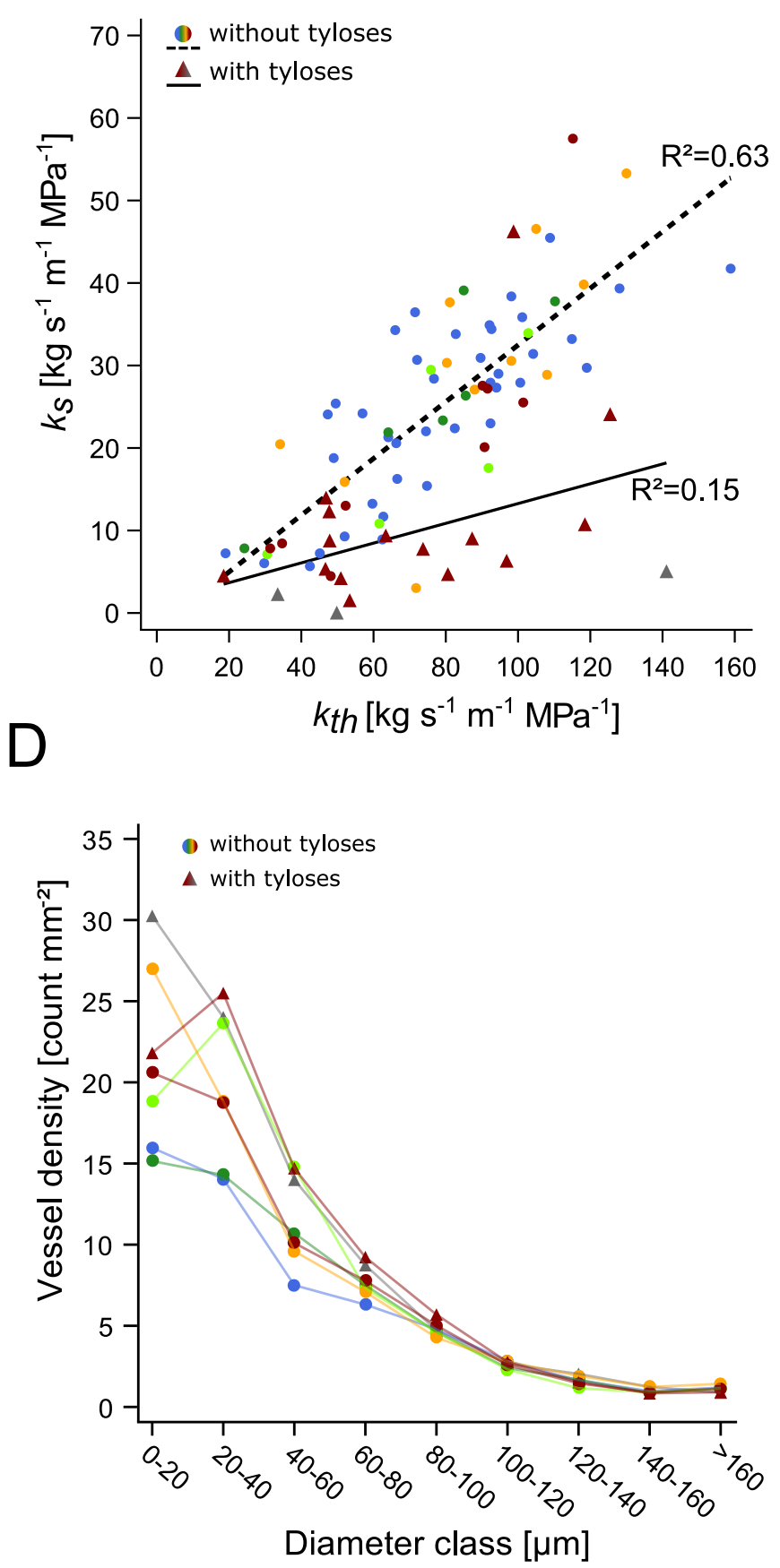

Fig. 4. Relationships between specific stem hydraulic conductivity $(k s)$, theoretical stem hydraulic conductivity $\left(k_{t h}\right)$, and vessel density in control and esca symptomatic grapevine plants. (A) $k_{s}$ values for control (blue); asymptomatic (dark green) and pre-symptomatic (yellow) stems in plants before symptom appearance; asymptomatic (light green), tiger-stripe (red), and apoplectic (grey) stems in plants after symptom appearance, differences were not significant $(\mathrm{n}=88, \mathrm{~F} 5,45=1.30 \mathrm{P}=0.28)$. Boxes and bars show the median, quartiles and extreme values, circles within boxes correspond to means, and circles outside boxes to outlier values. (B) Relationships between $k_{s}$ and $k_{t h}$. Symbols represent the absence (circles) or presence (triangles) of tyloses in xylem vessels. Colors represent esca symptomatology (as in panel A). The dashed line represents the regression for stems in which no tyloses were observed in xylem vessels, and the solid line represents the regression for samples with tyloses. $\mathrm{R}^{2}$ for the regression lines are indicated (see Table 2 and Fig. S4 for detailed analyses). (C) $k$ th values for the different stem categories as presented in panel a. Differences were not significant ( $\mathrm{n}=88, \mathrm{~F} 5,45=0.58, \mathrm{P}=0.71)$. (D) Relationships between mean values of xylem vessel density and their diameters. Differences in total vessel density and in vessel size distributions were not significant ( $\mathrm{n}=88, \mathrm{~F}_{6,45}=0.77, \mathrm{P}=0.60 ; \mathrm{n}=792$ ( 88 samples for 9 vessel classes), $\mathrm{F}_{48,693}=1.19, \mathrm{P}=0.18$ ). Colors and markers are the same as panel $\mathrm{B}$. 